\title{
KIRJAVIISIVAHETUS KIRIKURAAMATUTES
}

FRED PUSS

\begin{abstract}
Annotatsioon. Artikkel käsitleb üleminekut vanalt kirjaviisilt uuele luteri koguduste sünnimeetrikate põhjal. Vaadeldakse pastorite poleemikat vana ja uue kirjaviisi üle, esimesi uuele kirjaviisile ülemineku juhte ning eestlastest pastorite osa selles. 110 koguduse meetrikaraamatute põhjal tehtud analüüsist on esitatud statistiline kokkuvõte. Lisatud tabelis on ülevaade kõikide analüüsitud koguduste kohta uue kirjaviisi kasutusele võtnud pastorite andmetega.
\end{abstract}

Võtmesõnad: eesti keel, keeleajalugu, ortograafia, käsikirjateadus, nimeteadus, nimekorraldus, keelekorraldus

Ad vocem Kuusalu orikas - ta on naiivne; ta kujutab endale ette, et ta peen on - aga mis on siis jäme ja labane? Vastama ma pidin, kuid ega mul endale ometi midagi andeks anda ei ole? Jääb see siga nüüd viimaks rahule? Minu vastus on lühike ega tohtinudki pikk olla ja laulusõnu ei saanud ma ka pikemalt jätkata, sest seal järgneb kohe: karu persse kannikene, koera persse kaimukene.

Faehlmann Kreutzwaldile, 1849 (Kreutzwald 1976: 215-216)

\section{Sissejuhatus}

„Kuusalu orikas“ eeltoodud tsitaadis oli eesti keele uue kirjaviisi looja, Kuusalu pastor Eduard Ahrens. Vana ja uue kirjaviisi võitlus tekitas tuliseid tundeid juba 170 aastat tagasi ning see tekitab neid ka praegu. Nimelt ei ole harrastusajaloolased (kellest suurema osa moodustavad suguvõsauurijad) sugugi ühte meelt, kas kirikuraamatutesse raiutud nimekuju on püha või võiks seda kirjutada ikkagi nii, nagu nime tegelikult hääldati.

2009. aastal avastas artikli autor teemaga tegeledes, et nii Ahrens kui ka tema naaberpastor Jõelähtmest, Gustav Heinrich Schüdlöffel, läksid enda peetavates kirikuraamatutes uuele kirjaviisile üle lausa päevapealt. 
Avastus ei olnud tegelikult uus, nagu hiljem selgus: Jüri Kaugerand on oma bakalaureusetöös maininud seda juba kolm aastat varem (Hussar 2012: 38).

Artiklis vaadeldakse, 1) kas saab tõmmata mingeid piirjooni, millal kirikuraamatutes uut kirjaviisi kasutama hakati, 2) kas see protsess oli ühesuunaline, 3) kas see erineb Eestis piirkonniti, 4) milline oli olulisemate pastorite isiklik mõju teistele, 5) kas kirjaviisivahetust mõjutas eestlastest pastorite tulek või ametis oldud aeg.

\section{Vana kirjaviisi taust}

Vana kirjaviisi lõid XVII sajandi lõpus Bengt Gottfried Forselius ja Johann Hornung ning selle aluseks oli ülemsaksa ortograafia. Vanal kirjaviisil oli puudusi ning seetõttu tehti juba XVIII sajandil katseid selle parandamiseks (Anton Thor Helle, August Wilhelm Hupel). 1810.-1820. aastail tegelesid sellega näiteks Johann Heinrich Rosenplänter ja Otto Wilhelm Masing, soomepärast kirjaviisi soovitas kasutada soomlane Adolf Ivar Arwidsson juba aastal 1822. Järjepidev, kuigi aeglane üleminek uuele kirjaviisile Eestis sai alguse 1843, kui Ahrens soovitas soome keele eeskujul kasutusele võtta häälduspärase kirjaviisi ning avaldas oma eesti keele grammatika.

Vana kirjaviisi ajal polnud ortograafiareeglid ega nende kasutajad alati kõiges ühte meelt või nendest teadlikudki. Nii esinesid ühtaegu juba XVIII sajandil nimekujud Mari, Juhan, Jaan paralleelselt nimekujudega Marri, Juhhan ja Jahn.

Uue kirjaviisi levik oli vaevaline. Veel nähtavasti 1860 (sissekandes 1857. a kohta) leidis Jõelähtme pastor Kentmann, kes oli tolleks ajaks ise juba uuele kirjaviisile üle läinud, et uus kirjaviis ei leidnud rahva seas poolehoidu ja on kaheldav, kas ta üldse kasutust leiab ${ }^{1}$, kuna kõige tavalisemad ja levinumad kirjutised kasutavad piibli ortograafiat ning ajaleht Pärnu Postimees on tuliselt uuele vastu (Jõelähtme 2014: 106). Sama kroonika 1862. a sissekandesse (mis on tehtud 1863, pärast Ahrensi surma) kirjutas Kentmann, et Ahrens tegi palju eesti keele uurimise jaoks, kui ainult tema raamatud unustuse hõlma ei vajuks. Tõenäosus, et see nii läheb, on peaaegu olemas (Jõelähtme 2014: 115).

Läbimurre sündis Eesti Kirjameeste Seltsi eestkostel, kuna seltsi uut kirjaviisi pooldava 1872. a otsuse järel hakkas seda kasutama ka ajaleht

Kaldkirjas on täpne tsitaat kirjandusest või allikast, millele on viidatud (sh tõlgitud allikast), jutumärkides on autori tõlge või parafraseering. 
Eesti Postimees ning uus kirjaviis levis enam kalendrites ja kirjandusteostes. Uus kirjaviis saavutas ülekaalu aastail 1872-1875 (Kask 1958: 198). Arnold Kask (1958: 192) on pidanud vana ja uue kirjaviisi võitluse lõpuks uue testamendi ja piibli ilmumist (vastavalt 1888 ja 1889) uues kirjaviisis.

\section{Senised uurimused}

Üleminekut vanalt kirjaviisilt uuele on seni uuritud valdavalt trükisõna põhjal. Kask (1958: 161, 177, 192) on teinud kokkuvõtted raamatute kirjaviisist: 1869. a ilmunutest oli uues kirjaviisis viiendik, 1872-1874 ilmunutest umbes pool, 1875 kolmveerand ja 1879-1880 ilmunutest 90\%.

Vähe on aga uuritud käsikirjalisi allikaid. Meetrikaraamatute põhjal on teinud esimesi nimeanalüüse Edgar Rajandi ja Lemming Rootsmäe, kuid nende tööd ilmusid 1960. aastail ning allikatest (kirikuraamatutest) ja nende pidajate (kirikuõpetajate) mõjust kirjaviisile uurimustes juttu ei tehta. Mõlemal juhul (Rajandi 1963b; Rootsmäe 1969) on tegu uurimustega XVIII sajandi kohta, mil uuest kirjaviisist ei saanud juttugi olla, kuigi nimede eri kirjutusviis oli tollalgi tavaline. XIX sajandi nimesid uurides mainib Rajandi (osati koos Helmut Tarandiga) vaid paari üksiknime käsitluses vana kirjaviisi olemasolu (Rajandi 1963a: 110; 1963c: 690; 1965: 180; Rajandi, Tarand 1967: 177; 1969: 498), enamasti jätab selle aga üldse tegemata. Ka Rajandi ja Tarandi programmilistes ühisartiklites perekonnanimede uurimisest (Rajandi, Tarand 1966a; 1966b) puudutatakse vana kirjaviisi vaid möödaminnes (1966b: 401). XIX sajandi nimesid on eelkõige kirikuraamatute põhjal käsitlenud Eduard Roos (1962), kuid temagi ei käsitle nimede kirjaviisi.

Põgusalt on maininud nime kirjapanijate mõju selle kirjapildile Henn Saari, tuues näiteks, et kuigi sünnikandes võib inimese nimi olla näiteks Michael Alexander, võis ta kogu elu elada Mihklina, milline nimi oli ilmalikes dokumentides ning ka hauakivil. Saari mainib ka, et venestusajal (1890. aastatest) oli nime ametlik kirjapilt kirillitsas (nähtavasti mõtleb ta sünnikandeid), mis tekitas moonutusi, ning hilisemad nimekujud tekkisid mitteametlikult (Saari 1990: 8-9).

Esimesena mainib Kairit Henno oma uurimuses „Poeglaste eesnimed Pöide eesti koguduse 1801.-1840. aasta sünniregistreis“ pastori isikliku kirjutusviisi mõju - kui üks pastor kirjutas järjekindlalt Jaack, siis järgmine pastor kirjutas Jaak (Henno 2000: 31). 
Liisi Pärsiku ja Taavi Pae artiklis eesnimede piirkondlikest erinevustest Eestis 1840. a on põgusalt mainitud sünnisissekannete nimekujude teisendeid, kuid kirjaviisi erinevuste põhjustele pole tähelepanu pööratud (Pärsik, Pae 2011).

Alles Annika Hussar (2012) käsitleb artiklis „,Muutused eesnimekasutuses XIX sajandil Martna ja Palamuse näitel" uuele kirjaviisile üleminekut, seda poole lehekülje ulatuses, mainides, et uuele kirjaviisile läks üle Ahrens 1844, kuid artiklis käsitletavates kogudustes - Martnas ja Palamusel kindlat ajapiiri üleminekul tõmmata ei saavat. Siiski mainib Hussar, et Martnas mindi uuele kirjaviisile otsustavalt üle 1872 uue pastori tulekuga, kuid hiljem sellest jälle taganeti. Uus kirjaviis sai Martnas ülekaalu 1880. aastate teisel poolel. Palamusel on üksikuid juhte aastail 1877-1878, kuid need näivad juhuslike katsetustena. Hussar toob nimekirjutuses esile põhimõtte, et varasemad laennimed pandi kirja pigem vanas kirjaviisis, uued nimed järgisid valdavalt saksa kirjutustava (Hussar 2012: 38-39).

Hussar mainib ka, et paralleelselt peetud raamatutes on nimede kirjapilt ka samades sissekannetes erinev (Hussar 2012: 39). Olgu siinkohal selgitatud, et meetrikaraamatuid peeti kahes eksemplaris, millest üks oli pidevalt peetav algeksemplar, teine aga iga aasta algul ühekorraga kirjutatud ärakiri eelnenud aasta andmetest. Ärakiri ei olnud sageli algeksemplari kirjutaja enda ümber kirjutatud ning võis kajastada ümberkirjutaja (abipastori, köstri) suhtumist õigekirja (vt allpool Otepää näidet). Muidugi võis ebajärjekindlust kohata ka ühe ja sama kirjutaja puhul.

Oma järgmises samateemalises uurimuses Hussar vana kirjaviisi küsimust ei puuduta, küll aga käsitleb ta käesolevaski artiklis olulist üleminekut venekeelsetele meetrikaraamatutele aastal 1892 (Hussar 2014: 52-53).

Esimene uurimus otseselt nimede kirjaviisi kohta kirikuraamatutes (ja hauatähistel) pärineb Pille Arnekilt (2013a). Ta võrdleb nimede kirjapilti XIX sajandi hauatähistel ja meetrikaraamatutes, meetrikaraamatute sissekannetest on ta kasutanud üksnes nende inimeste surmasissekandeid, kelle nimi on olnud hauatähistel. See aga ei anna tõest ülevaadet kirjaviisi kasutuse kohta koguduseti.

Arnek (2013a: 412) leiab põhjendatult, et pastorid ei kontrollinud isikunime varasemat kirjapilti, vaid kirjutasid endale harjumuspärasel moel ning sellest võisid tulla väiksemad täheerinevused. Samas toob Arnek (2013a: 413) välja sellele vastu käiva tõdemuse, et kui kord sai sünnimeetrikasse kirja eestipärane nimi, siis on pastor seda kasutanud 
ka hiljem. Sellist seisukohta siinne uurimistöö ega selle autori empiiriline kogemus ei kinnita - nime kirjapilt olenes konkreetselt pastori suhtumisest kirjaviisi ja nimedesse. Kui üks pastor oli nime kirjutanud uues kirjaviisis, võis järgmine pastor seda ikkagi kirjutada vanas ja loomulikult ka vastupidi. Sama kehtis nimede keelsuse kohta: ühe pastori kirja pandud nimest Mihkel võis järgmise pastori puhul saada Michel. Arnek esitab näiteid selle kohta, et kirikuraamatus esines isikul eestikeelne perekonnanimi (Rosimäe), hauatähisel aga saksakeelne (Rosenberg), ning tõdeb, et kui kirikuraamatus on endiselt eestipärane nimi, siis ei ole nime ametlikult muudetud (2013a: 414). Siin võib asi olla aga hoopis selles, et samal isikul või tervel suguvõsal võisid eriotstarbelistes allikates (hingekirjutuse süsteemi allikad versus kirikuraamatud) olla erisugused nimed.

Kokkuvõtlikult leiab Arnek, et hauatähistel oli kasutatud uut kirjaviisi kirikuraamatutest veidi enam ning kui 1870 . aastail jäi see mõlema puhul viiendiku kanti, siis 1880. aastail tõusis üle poole (2013a: 417).

Oma teises artiklis mainib Arnek (2013b), et üleminek hauatähiste tekstides on näha Põltsamaal 1860. aastail, järgnesid teised kihelkonnad ning 1880. aastaist on hauatähiste tekstid peaaegu kõik uues kirjaviisis, vanas kirjaviisis leidub vaid üksikuid sõnu ja nimesid. Pirital ja Ilumäel saab uus kirjaviis valdavaks alles sajandi lõpukümnendil. Huvitav on Arneki tähelepanek, et kui enamasti oli üleminekuajal kasutusel segastiil, siis Põltsamaal segastiili ei kasutatud (Arnek 2013b: 484).

Olgu siin tsiteeritud ka teemat puudutanud Jakob Hurta (1864: 14), kes oma „Lühikeses õpetuses“ uuest ortograafiast selgitab: Nimed, mis wana wiisi puudulikult kirjutati, peawad uut wiisi ümberkirjutatama, nii et nime kirjutamine ja wäljaütlemine kokku käiwad ning toob näiteks Jaan Kübar, Toomas Hämalane, Mari Kadakas jt.

\section{Analüüsiks kasutatud allikad}

Allikad, mille põhjal on artiklis analüüsitud kirjaviisi kasutuse dünaamikat, on luteri koguduste meetrikaraamatud ehk kronoloogiliselt peetud ristimiste, laulatuste ning matmiste registrid (mida kutsuti ka kirikuraamatuteks). Kuigi neisse tehti mõnikord sissekandeid viivitusega, ei ulatu see enamasti üle ühe aasta ega ole seetõttu oluline. Personaalraamatuid ehk perekonnaraamatuid oleks samuti võimalik kirjaviisi kasutamise analüüsil kasutada, kuid nende puhul tuleks kasutada hulgaliselt paleograafilist 
analüüsi, selgitamaks, millised on raamatut alustades kirja pandud nimed ning mis on hiljem lisatud. Mõnikord peeti ühte ja sama personaalraamatut väga pikka aega (näiteks Hallistes 1836-1939, Vastseliinas 1820-1903) ning sissekannete dateerimine on aeganõudev. Seetõttu on käesolevas töös tuginetud enamasti sünnimeetrika sissekannetele.

Luteri kogudustes peeti alates 1834. aastast vähemalt kaht meetrikaraamatu eksemplari - üks neist oli koguduse kätte jääv algeksemplar, teine koostati iga aasta algul eelnenud aasta andmeid ümber kirjutades ning see saadeti konsistooriumile säilitamiseks. Ümberkirjutust ei teinud sageli algeksemplari koostanud pastor, vaid mõni tema abiline, seega võis sinna sattuda algeksemplariga võrreldes teisi nimekujusid. Siin töös on kasutatud enamasti algeksemplare, vajaduse korral ärakirju (kui on selgeks tehtud, et need on kirjutatud pastori käekirjaga, algeksemplar aga mitte). Näide selle kohta, kuidas algeksemplar on uues, ärakiri aga vanas kirjaviisis, on toodud allpool pastor Hurda ja köster Anveldti puhul. Vastupidise näite saab tuua Vaivarast, kus uuele kirjaviisile mindi üle 1880. aastal ning 1879. aasta vanas kirjaviisis meetrikast tehti konsistooriumi jaoks 1880 ärakiri juba uues kirjaviisis.

Vene 1832. a kirikuseadus ega muud määrused ei puudutanud kirikuraamatutes kasutatavate nimede õigekirja. Vaid venestusajal, kui 1892. aastast oli kohustuslik kirikuraamatuid (kuid mitte personaalraamatuid) pidada vene keeles, anti välja juhendeid eesnimede kirjutamiseks kirillitsas. Enamasti peetigi meetrikaid 1892. aastast vaid vene keeles ning sageli eesnimedele ladina tähtedega vastet ei kirjutatud, seda tehti tavaliselt ainult perekonnanimede puhul, mõnel puhul mitte sedagi. Koguduses võis peale kahe mainitud eksemplari olla veel mustandeksemplare, mis võisid olla ka venestusajal täielikult ladina tähestikus, kuid need on erandid. Seetõttu jääb vanalt kirjaviisilt uuele ülemineku analüüs sageli 1892. aastasse toppama, kui selleks ajaks üleminekut veel toimunud polnud.

Õigeusu kirikuraamatud võeti kasutusele Lõuna-Eestis õigeusu leviku ja koguduste asutamise tõttu enamasti 1840. aastate teisel poolel, PõhjaEestis 1880. aastate keskel. Tööst on need kõrvale jäetud põhjusel, et neis pole võimalik kirjaviisivahetust jälgida - raamatuid on peetud vene keeles ning kasutatud on üldjuhul õigeusu ristinimesid, mille kirjapilt oli vene keeles juba selleks ajaks ühtlustunud.

Vältimaks teksti koormamist arhiiviviidetega, on need ära jäetud, kui tegu on sünnimeetrikatest saadud andmetega. Konkreetse koguduse 
soovitud aasta meetrikaraamatute kõikide eksemplaride veebilingid rahvusarhiivi digiteeritud arhiiviallikate kogus leiab kõige hõlpsamini meetrikate andmebaasist http://www.genealoogia.ee/esivanemad/aastareg/.

\section{Metoodika}

Töös on analüüsitud eesnimede kirjaviisi, kusjuures kasutatud on ristitud laste ning ka nende vanemate ja vaderite nimesid.

Üleminek vanalt kirjaviisilt uuele võis olla järsk või järkjärguline. Mõnel puhul on üks ja sama pastor hakanud osa nimesid kirjutama uues kirjaviisis, osa kirjutamist jätkas aga vanas. Sellises segakirjaviisis esinevad mõned uuele kirjaviisile omased tunnused - kõige sagedamini kadus esimesena ära topeltkonsonant uue silbi algul: Jürri > Jüri, Juhhan > Juhan, Kaddri $>$ Kadri, kuid samal ajal jäid kasutusele nimed Leno, Wio, Karel, Peter. Nende üksikute muutuste tekkimist pole siin töös arvestatud veel uuele kirjaviisile üleminekuna, kuna need tunduvad olevat pooleldi alateadlikud, sageli on need ka äärmiselt ebaühtlased - poeg võis olla Jürri, isa aga samas sissekandes Jüri jne. Ka eesti rahvusest pastorite kirjaviisi kasutus polnud ühtlane ning tõenäoliselt kasvas enesekindlus uut kirjaviisi kasutada koos ajaga.

On märgata, et neil uutel pastoritel, kes ametisse astumisel võtsid uue kirjaviisi kasutusele senise vana asemel, läks esialgu mõni aeg kohanemiseks - algul esineb mõnel puhul veel vana või segakirjaviisi, kuid mõne kuu pärast on stiil ühtlustunud.

Kuna segakirjaviisi kasutamise puhul ei saa üleminekut täpselt dateerida, on lähtutud sellest, millal tundus kirjutaja olevat püüdnud hakata uut kirjaviisi vanale eelistama, kuigi tal võis edaspidigi esineda ebaühtlust. Segakirjaviisi pikemaaegne kasutamine pigem uue kirjaviisiga sarnaneval juhul on tabelis tähistatud tärniga. Kui segakirjaviis sarnanes rohkem vana kirjaviisiga, pole seda üleminekuks loetud. Üleminekuaasta märkimine siin töös on seega sageli tinglik ning empiirilise, mitte aga statistilise meetodi tulemus, kuid see näitab kindlasti üldist tendentsi. Kindlasti esineb juhte, kus mõnele pastorile on liiga tehtud, lugedes teda vana kirjaviisi kasutajaks, mõnda teist sama usina katsetuse tegijat aga juba uue kirjaviisi kasutajaks. Vaid üksikutel juhtudel on näha vana või uue kirjaviisi järsku vahetumist, sageli oli mitu aastat aega kasutusel segakirjaviis, mis kogu XIX sajandi jooksul liikus vana poolt uue poole, kuid mitte hetkega. 
Segakirjaviisi olemasolu tingis kindlasti ka pastorite vähene eesti keele nüansside tundmine. Juba mainitud pastor Kentmann kirjutas 1862. a kohta Jõelähtme koguduse kroonikasse tolle aasta sinodil toimunud Ahrensi keeleteemalise ettekande kohta (mida sinodi protokolli teiste vastuseisu tõttu ei lisatud), et meil on piisavalt jutlustajaid, kes räägivad head arusaadavat eesti keelt, aga puudub korralik (correcter) ja ühtne keeleseadus. Paljud neist on mulle öelnud, et kui nad räägivad ühe jutiga (im Schwall reden), on kõik hästi, aga kui nad hakkavad väljendite ja vormide üle järele mõtlema või peavad midagi kirjutama, siis ei taha asi paigast nihkuda (Jõelähtme 2014: 114).

Segakirjaviis polnud omane vaid sakslastest pastoritele. Näiteks Nõos oli järjest ametis kaks eestlasest pastorit: 1878-1883 Jürmann ${ }^{2}$ ja 1884-1923 Lipp. Jürmann kasutas ametisse asumise aasta algul segakirjaviisi (Mari, Jüri, Kadri, aga Peter, Jula, Lena), sama aasta lõpul aga juba pigem uut kirjaviisi (Triin, Liisu, Peedu, Miina, aga Peter, Wio, viimasest sai 1879 Wiju). Lipp alustas peaaegu täiesti uues kirjaviisis (Liisa, Mihkel, Johan, Mari, Jüri, Aadu, Wiiu Wiio), kuigi algul eksis hulka ka mõni üksik Marri, nähtavasti automaatselt vanast kirikuraamatust ümber kirjutades. Kuid segadust tekitas talle nimi, mis mõnikord lapse isa nimena oli Peeter, sama lapse vaderi nimena aga Peter. Umbes poole aasta pärast oli Lipu kogemus suurenenud ning kirjaviis ühtlustunud. Nimekuju Peter jäi ta aga paralleelselt kasutama oma ametiaja lõpuni, eelistades seda nimekujule Peeter, nähtavasti kohaliku häälduse tõttu. Uut kirjaviisi oli Lipp kasutanud muidugi ka juba Kaarmas 1882 pastoriametisse asudes. Sellise lühiajalise ülemineku puhul segakirjaviisilt uuele on loetud üleminekuajaks aasta, mil empiirilisel vaatlusel enamik nimesid kirjutati uues kirjaviisis.

Mõni pastor kasutas aga mitukümmend aastat segakirjaviisi. Näiteks Pühalepa pastor Normann (ametis 1880-1897) kasutas ladina tähestikus meetrikaraamatute pidamise ajal (1880-1891) paralleelselt nimekujusid Liso ja Liiso, Lena ja Leena, Maddis ja Madis, Jürri ja Jüri jne, samas kui mõni nimi muutus 1891. a paiku ning Peterist sai üsna järjepidevalt Peeter, Pridost Priido jne. Neid uue kirjaviisi nimekujusid varem ei esinenud. Üldine tendents Normanni puhul on uues kirjaviisis nimede osakaalu pidev suurenemine, kuid nagu näha, toimus see enam kui aastakümne jooksul.

2 Edaspidi on pastorite puhul lihtsustamise huvides kasutatud koguduse nime ja vaid perekonnanime. Pastorite andmed on pärit vastavatest teatmikest (Schmidt 1939; Prediger Livlands 1977; Pastoren Estlands 1988; Aarma 2007). 
Väga pikaajaline üleminek oli ka näiteks Helme pastoril Behsel (ametis 1857-1897). Kui Kaddri asemel hakkas ta enam-vähem püsivalt Kadri kirjutama 1860. a paiku (jätkas aga nimede Maddis ja Äddo kasutamist), siis enamikku teisi nimesid uues kirjaviisis alles 1871. Paraku taandus ta sellest juba kahe aasta pärast, et alles 1880. aastate teisel poolel uuesti uus kirjaviis kasutusele võtta. Sellistel juhtudel on esimene uuele kirjaviisile üleminek loetud üleminekuajaks ning tabelis on ära märgitud hilisemad muutused. Väga lühikesi (alla aasta) uue kirjaviisi katsetusi pole loetud üleminekuajaks ning võimalik, et osa neist on jäänud märkamata (vt allpool).

Helme on ka hea näide selle kohta, kui keerukas võib olla jälgida konkreetselt ühe pastori kirjaviisi muutust. Nimelt oli Helmes palju abipastoreid ning sageli täitis kirikuraamatuid ka köster. Seega tuli kõigepealt selgeks teha pastori käekiri ning jälgida muutusi ainult selle käekirjaga tehtud sissekannetes. Üleminekuaegadel, kui uut pastorit veel polnud (enamasti alla aasta), on sissekandeid teinud asendajad (eelkõige naabervõi vikaarpastorid, sageli köstrid). Nende tehtud sissekannete kirjaviisi pole siin arvesse võetud, välja arvatud pikemad asendamised (näiteks Kaarmal).

Pastori käekirja tuvastamiseks tuli sageli otsida tema allkirjaga dokumente (nt koguduse tehtud väljavõtteid kirikuraamatutest teise kogudusega liitumiseks ehk kirikutähti, mida leidub eelkõige naaberkoguduste materjalide hulgas). Nii selgus, et Paistu pastor Bergmann ei kirjutanud meetrikaraamatuid peaaegu kunagi ise, tehes aeg-ajalt sissekandeid vaid saksa pihtkonna raamatuisse; samuti Võnnu pastorid Oehrn (noorem) ja Vares ei kirjutanud ise eesti pihtkonna meetrikaid. Seetõttu on selliste pastorite kirjaviis jäänud selgusetuks. Ei saa ka välistada mõningaid eksimusi, kus köstri käekirjaga (mis on sageli olnud pastori omaga äärmiselt sarnane) tehtud sissekandeid on peetud pastori omadeks.

Kuna andmestiku suure mahu tõttu polnud võimalik kõikide koguduste kõikide aastate sissekandeid analüüsida, on seda tehtud pastorivahetuse paiku. On jälgitud, mis kirjaviisi kasutas ametisse asunud pastor alguses, ametiaja jooksul (pisteliselt) ning selle lõpul (enamasti kattus see ka elu lõpuga). Kui selget muudatust ametiaja alguses ja lõpus kasutatud kirjutusviisi vahel polnud, pole vahepealseid aastaid analüüsitud. Seetõttu võis märkamata jääda mõni üleminekukatsetus, millest on hiljem taandutud, kuid tõenäoliselt on tegu pigem eranditega. Samuti pole uuele kirjaviisile ülemineku järel tehtud sissekandeid enam edasi analüüsitud, välja arvatud 
mõni väga varase üleminekuga kogudus. Enamasti toimus üleminek juba niivõrd hilja, et sellest hilisem taandumine pole väga usutav, kuigi tuli ette sedagi. Uue kirjaviisi varajaste kasutusele võtjate ametijärglaste mõningad taandumised või jätkamised on märgitud tabelis, kuid need andmed ei pretendeeri täielikkusele.

Perekonnanimesid ei saa kirjaviisi muutuse jälgimisel samahästi kasutada kui eesnimesid, kuna perekonnanimed on alati olnud muutuste suhtes konservatiivsemad ning neis kohati praegugi kasutatav vana kirjaviis (Karro, Leppik jne) on siirdunud ka nende hääldusse. Ka eesnimede puhul mängib kindlasti rolli asjaolu, et andmeid kirjutati pidevalt vanadest raamatutest uutesse ümber ning mõni tagasihoidlikuma keelevaistuga või üldiselt alalhoidlikum pastor kasutas seetõttu sama kirjaviisi, mida tema eelkäija.

\section{Uue kirjaviisi esimesed kasutajad}

Nagu mainitud, sai uue kirjaviisi levik uue tõuke Kuusalu pastori Ahrensi 1843. aastal avaldatud eesti keele grammatikast. Tema kolleege, Eestimaa pastoreid, mõjutas ehk rohkemgi tema sõnavõtt 1844. a juunis Eestimaa provintsiaalsinodil. 1845. a juunis esines Ahrens taas sinodi koosolekul uue kirjaviisi teemadel ning kuigi vaieldi pikalt, oli enamik kirjaviisi parandamise vastu (Vilbaste 1961: 11-12). Arvati, et seda võiks katsetada ilmalikes teostes, kuid mitte kirikukirjanduses. Ahrensi ettepaneku vastu oli 16, poolt 5 häält. Poolt hääletasid peale Ahrensi enda veel Vigala pastor Harten, Lüganuse pastor Vogt, Kadrina pastor Hellenius ja Harju-Jaani pastor Danielsson (Kask 1958: 57).

Ahrens ise kasutas 1843. aastani oma kirikuraamatutes vana kirjaviisi. Eesnimedena pani ta kirja järgmised: Tomas, Josep, Juhhan, Tönno, Jürri, Marri, Leno, Liso, An, kohanimedena: Kiohabla, Winnisto, Mäpä, Kabberneem, Harra. Kohe 1844. a alguses läks ta esimesena üle uuele kirjaviisile, võttes kasutusele eelmainitud nimede asemel vastavalt Toomas, Joosep, Juhan, Töno, Jüri, Mari, Leeno, Liiso, samaks jäi An (ühesilbilise sõna lõpul oleva pika konsonandi märkimine oligi uues kirjaviisis veel kaua kõikuv), ning kohanimedest kirjutas uues kirjaviisis vastavalt Kiohaabla, Winisto, Mäepää, Kaberneem, Hara. 1850 tegi ta veel ühe uuenduse, asendades järgsilbi $o$ tähega $u$ : eesnimed Tönu, Liisu, Leenu, kohanimed Kiuhaabla, Wiinistu, Kõnnu. 
Ahrens ei kasutanud uut kirjaviisi aga alati ja igal pool. Näiteks kui konsistoorium palus temalt 1847. a andmeid Kose koguduse liikme Lena Kunderbergi vastsündinud lapse kohta, siis kasutas ta oma vastuses nimekuju Lena, kuigi oma koguduse liikmed oli ta selleks ajaks juba Leenadeks ümber kirjutanud (EAA.1216.1.11, pagineerimata).

Ahrens oli viimased kolm eluaastat (1860-1863) ka Ida-Harju praost. Siiski tundub, et tema mõju praostina polnud suurem kui pastori ja kirjamehena. Ida-Harju praostkonnas läksid pastorid üle uuele kirjaviisile üsna vaevaliselt: Kosel 1881, Juurus 1882, Jüris 1886, Harju-Jaanis pärast 1891. aastat. Ka Kuusalu piirinaabrid teistes praostkondades ei olnud keskmisest agaramad - Amblas tuli uus kirjaviis kasutusele 1879, Kadrinas 1887.

Kuusalu pastorina järgnes Ahrensile 1863 Kentmann, kes kasutas kirikuraamatutes kohe uut kirjaviisi. Ahrensi ja Kentmanni vahepeal lühikest aega olnud asendajad kasutasid aga vana kirjaviisi.

Kuusalus oli Kentmanni juures 1870-1871 prooviaastal Beater. Sealt läks ta edasi Väike-Maarjasse, kus oli aga vaid aasta ning lahkus Peterburi Jaani kogudusse. Sealgi polnud ta kaua, vaid siirdus edasi Valjalasse. Igal pool kasutas ta segakirjaviisi, mis oli küll rohkem vana kirjaviisi sarnane. Seega tema puhul Kentmanni juures õppimine ei mõjunud. Tema nimekirjutusviisist lausa õhkub tunnet, et uus kirjaviis ei sobinud talle põrmugi - kohati ta seda proovis, kuid järgmise sissekande juures juba unustas.

Ahrensi lähimaid kaastöölisi uue kirjaviisi alal oli Jõelähtme pastor Schüdlöffel. Nad olid regulaarses kirjavahetuses ning ,tsenseerisid ja kritiseerisid“" teineteise kirjatöid (Jõelähtme 2014: 106). Schüdlöffel läks teisena kohe 1844. a alguses oma kirikuraamatutes üle uuele kirjaviisile, kusjuures järgsilbi muutuse $o>u$ võttis ta kasutusele Ahrensist üle kahe aasta varem - septembris 1847. Jõelähtmes järgnes Schüdlöffelile juba nimetatud Kentmann, kes oli seal kolm aastat enne Kuusallu asumist. Ta kasutas Jõelähtmeski kohe 1860. aastast uut kirjaviisi. Talle 1863 järgnenud pastor Loppenowe kasutas segakirjaviisi, mis aga pikapeale oli rohkem uue kui vana kirjaviisi moodi.

Ahrensi juba mainitud pooldaja, Lüganuse pastor Vogt võttis uue kirjaviisi kolmanda pastorina kasutusele 1844. a juulis, seega kohe pärast Ahrensi sõnavõttu sinodil. Nendele lisandus neljandana veel üks Ahrensi naaber - Haljala pastor Striedter, kes läks uuele kirjaviisile üle 1844. a detsembris. Nii Vogt kui ka Striedter olid ametis 1880. aastateni, seega 
nende järglased kasutasid samuti juba uut kirjaviisi, kuna tolleks ajaks oli see saanud üldlevinuks.

Seega 1845. a sinodil Ahrensi ettepanekute poolt hääletanud viiest pastorist läks uuele kirjaviisile oma ametiajal (ja seda juba 1844) üle vaid Lüganuse pastor Vogt. Harju-Jaani pastor Danielsson katsetas uut kirjaviisi, kirjutades 1848. aastast Jürri ja Marri asemel Jüri ja Mari, kuid jätkas nimekujude Liso, Tio, Tina, Juhhan kasutamist oma Eestis tegutsemise lõpuni.

Ka Keila praost Fick, kes 1845. a sinodil esines koos Ahrensiga teemal „Kuidas tuleb teostada meie eesti kirikukeele reformi“ (Paul 1999: 559-560), ei läinud oma 1883. aastani kestnud ametiajal uuele kirjaviisile üle. Pühalepa pastor Sengbusch (ametis 1822-1877), kes esitas 1845. a sinodil igasuguse parandamise vastu protesti, oli vastuoluline ja konservatiivne isiksus. Ta teadis peast Ahrensi grammatika põhireegleid paragrahvide kaupa ning võrdles 1860. a sinodil Schüdlöffeli uue testamendi tõlget Ahrensi grammatika reeglitega (Paul 1999: 560, 572, 574-575), kuid oma peetavates meetrikaraamatutes jäi Sengbusch muutumatult vana kirjaviisi juurde.

Uue kirjaviisi katsetajatest leiame Järva-Madise kogudusest pastor Hirschhauseni, kes 1853 sinna ametisse saades kirjutas algul küll Leeno, Aadam, Thoomas, Triino, Kaarel, Mari, Jüri, kuid järgmisel aastal naasis vana kirjaviisi juurde. Muide, Hirschhausen oli Ahrensile eelnenud Kuusalu pastori poeg. Ehk proovis ta seepärast just 1853 Ahrensi grammatika teise trüki järgi uut kirjaviisi, kuid see talle ei sobinud.

Alates 1844. aastast võttis viiendana uue kirjaviisi kasutusele Rapla pastor Haller aastal 1853. Ta oli Käina pastori poeg, tegutses Raplas koolide arendamisel, kohaliku piibliseltsi ja laste varjupaiga asutamisel, oli Eestimaa Kirjanduse Ühingu liige ning kirjutas ka mõne saksa- ja eestikeelse raamatu piibliseltside tegevusest. Pastorina olnud ta karm, kuid austatud (Aarma 2011: 2-3).

Kaht viimati mainitud pastorit mõjutas tõenäoliselt Ahrensi grammatika teise trüki ilmumine 1853.

Kuigi Rapla järgmine pastor Malm jätkas 1864. a ametisse asudes oma meetrikates eelkäija uut kirjaviisi, ei teinud ta seda alati trükisõnas. Seepärast pahandas temaga Kreutzwald kirjas Hurdale (17. I 1865): Kui härra Malm, nagu Teie mineval suvel tähendasite, sähendustele eeslitele meeldimiseks on uuest kirjaviisist ära taganenud, siis on ta väärt, et temale näkku süljataks! (Kreutzwald 1976: 89). 
Karuse pastor Hasselblatt üldiselt pooldas 1845. a sinodil Ahrensi ideid, kuid arvas, et nõu tuleks küsida ka Liivimaa sinodilt ja piibliseltsilt ning ei hääletanud seetõttu Ahrensi poolt (Paul 1999: 560). Uuele kirjaviisile läks ta üle oma meetrikaraamatutes 1858, olles sellega järjekorras kuues. Kuna Hasselblatt kasutas uut kirjaviisi ka oma luuleraamatus (ilmus 1861), tunnustas teda selle eest Kreutzwald kirjas Hurdale (17. I 1865): Russow ja Hasselblatt on sakslased ning julgevad [erinevalt Malmist - FP] vastuvoolu ujuda, oma jõudu mööda paremini kirjutada (Kreutzwald 1976: 89).

Järva-Jaani praost Gebhardt kontrollis konsistooriumi korraldusel Schüdlöffeli uue testamendi uuekirjaviisilist redaktsiooni ning märkis 1860. a sinodil, et tema ei ole nõus [vanakirjaviisilisele redaktsioonile FP] tagasi minema (Paul 1999: 570, 572). Samas oma ametiaja lõpuni aastal 1861 ta uut kirjaviisi kasutusele ei võtnud. Seda ei teinud tema ametis jätkanud poegki, kes suri 1902.

1871. a sinodil pooldas Viru praostkond ainsana uue kirjaviisi rakendamist Ferdinand Johann Wiedemanni tehtud piibliredaktsioonis, kuid seda ettepanekut ei toetatud. Viru praost Paucker oli juba 1861. a sinodile saadetud kirjas tugevalt kritiseerinud piibliseltside vastutöötamist Eestimaa vaimulike püüetele piibli keelt parandada (Paul 1999: 572-573, 579). Oma kirikuraamatutes jäi Paucker aga vana kirjaviisi juurde.

Haapsalu pastor Hörschelmann väitis 1845 . a sinodil, et tema poolt koguduse liikmetele esitatud küsimuse peale keele parandamise kohta anti sellele eitav vastus. Tema vennapoeg, Ridala pastor Hörschelmann katsus näidata, et senine kirjakeel on täiesti arusaadav ja reform tekitaks raskusi (Paul 1999: 560-561). Huvitaval kombel olid aga mitmed Hörschelmannid need, kes ülejäänud Eestiga võrreldes läksid pigem varakult uuele kirjaviisile üle: nimetatud Ridala pastori poeg samas Ridalas (1869, Eestis kümnes, kes hakkas uut kirjaviisi oma koguduse raamatutes kasutama), tema lellepoeg Martnas (1872), teine lellepoeg Karusel (1870 jätkas eelmise pastori uut kirjaviisi), isa lellepoeg Kosel (1881, tema poeg jätkas uut kirjaviisi), Kose pastori õepoeg, Viru-Jaagupi pastor Hoffmann (1873). Samas oli ka paar pastorit samast Hörschelmanni perekonnast, kes 1880. aastail jätkasid vana kirjaviisi kasutamist.

Paljud pastorid oli ametis vaid ühes koguduses kuni surmani. Nende puhul, kes liikusid ühest kogudusest teise, on huvitav jälgida, kuidas nende kirjaviis muutus. Näiteks Hagerisse tõi Karuselt uue kirjaviisi üle Hörschelmann, temale oli ametis eelnenud ta vanem vend, kes ei kasutanud 
uut kirjaviisi. Noorem Hörschelmann oli varem (1870-1886) ametis olnud aga Karusel ning seal oli juba 1858 pastor Hasselblatt uuele kirjaviisile üle läinud. Küllap see mõjutas ka Hörschelmanni, kes kasutas uut kirjaviisi kohe ka Karusel Hasselblatti ametis jätkates.

Hörschelmannid andsid uue kirjaviisi varase kasutamisega tooni kogu Läänemaal, kuid esimene oli seal Lääne-Nigula pastor Frese aastal 1865, olles kogu Eestis seitsmes, kes esimesena oma koguduses uue kirjaviisi kasutusele võttis (enne teda Schüdlöffeli ametijärglane Kentmann 1860 ning Halleri järeltulija Malm 1864 jätkasid oma eelkäija uue kirjaviisi kasutamist). Frese vend, Tallinna Jaani pastor Frese, võttis 1870. aastal samuti uue kirjaviisi kasutusele, kuid loobus sellest veel samal aastal. 1880-1885 oli ta pastor Kuressaares, kus samuti ei kasutanud uut kirjaviisi, 1886. aastal Reigisse minnes võttis seal aga uue kirjaviisi käibele.

Mandri-Liivimaa esimene uue kirjaviisi kasutusele võtja aastal 1867 oli Eestis alles kaheksas-üheksas. See oli Tarvastu pastor Carlblom (ametis 1842-1872). Ta oli keskmisest suurema annetusega Aleksandrikooli esialgsete asutajate hulgas (Kruus 1939: 42) ning rääkis Kreutzwaldi järgi niihästi läti keelt kui ka mõlemaid eesti dialekte (Kreutzwald 1976: 568). Kohalike elanike mälestuste järgi oli ta rahvale nälja- ja ikaldusaastail abiks, kuid rahvaga läbikäimine oli raskendatud väga palju, sest et ta halvasti kõneles eesti keelt. Rahvas jäi tema ajal väga tuimaks ja hooletuks, jutluse ajal tukkus ja ajas juttu (Ajalooline traditsioon).

Saaremaal võttis esimesena uue kirjaviisi kasutusele Pöide pastor (1867-1901) parun Nolcken ning seda kohe ametisse asudes, olles koos Tarvastu Carlblomiga Eestis kaheksas-üheksas. Ta on tuntud eesti keele ja folkloori uurijana ning keelemehena, kes lõi eesti keele kolme välte märkimiseks oma kirjaviisi (Peegel 1959: 50).

Eestlastega hea läbisaamine või huvi keele vastu polnud aga alati seotud kirjaviisivahetusega. Näiteks kinnitati Rõngu pastoriks 1880 senine abipastor Hesse, kelle vastu olid koguduse liikmed. Ta oli eestlaste rahvuslike püüete eitaja ning tema käest ei tahtnud suurem osa kogudust armulaua sakramentigi vastu võtta, esines koguni tahtlikke süütamisi ja relva kasutamist (Saard 2000: 148). Siiski võttis just tema esimesena Rõngu koguduses uue kirjaviisi juba 1881 kasutusele.

Seega enne 1870. aastat olid läinud uuele kirjaviisile üle vaid kümne koguduse pastorid ning uut kirjaviisi oli hakanud kasutama 12 pastorit (st kaks neist jätkasid ametis eelnenu uut kirjaviisi). 


\section{Kirjaviisivahetuse analüüs}

Analüüsitud on 110 koguduse meetrikaraamatuid - 52 Eestimaalt (Ha 13, Jä 7, Lä 15², Vi 13, Tln 4) ja 58 Liivimaalt (Pä 10, Sa 13, Ta 17, V1 9, Võ 9). Nendest läks 1891. aastaks, mis ajani on võimalik kogu Eesti kohta andmeid analüüsida, üle uuele kirjaviisile 76 kogudust (69\%). Neist 16 jäid pikemaks ajaks pidama segakirjaviisile, mis oli siiski üsna sarnane uue kirjaviisiga. Neid, kes kuni mõne aasta jooksul läksid enam-vähem puhtale uuele kirjaviisile üle, pole viimaste hulka loetud.

76-st kirjaviisi vahetanud kogudusest asus Eestimaal 39, seal läksid uuele kirjaviisile üle 75\% kogudustest (Ha 11 - 85\%, Jä 3-43\%, Lä 13 87\%, Vi $9-69 \%$, Tln $3-75 \%$ ), Liivimaal 37 ehk 64\% (Pä $8-80 \%$, Sa $10-77 \%$, Ta $8-47 \%$, V1 $9-100 \%$, Võ $2-22 \%$ ). Seega kõige enam oli 1891. aastaks uuele kirjaviisile üleläinuid Viljandi-, Lääne- ja Harjumaal, kõige vähem Võru-, Järva- ja Tartumaal.

Järvamaa puhul oli tegu tõenäoliselt konservatiivsemate pastoritega, kes väikeses praostkonnas suuremat mõju avaldasid. Koeru praost Hoffmann kasutas küll segakirjaviisi, kuid mitmed teised (Ambla Knüpffer, Järva-Madise Nerling, Järva-Jaani Gebhardt) veel 1880. aastail üsna puhast vana kirjaviisi.

Võru- ja Tartumaa pastorite vastumeelsust uuele kirjaviisile aitab selgitada Arnold Kask (1970: 186, 188, 191), kes on toonud välja, et Lõuna-Eesti pastorid ei pooldanud põhjaeesti keelel põhineva rahvuskeele tarvitamist ja võitlesid visalt lõunaeesti kirjakeele säilitamise eest ning väljasurev lõunaeesti kirjakeel säilitas üldiselt ka vana kirjaviisi.

Kohe uues koguduses ametisse asudes (aasta jooksul) võttis uue kirjaviisi kasutusele 32 pastorit, nendest 11 jaoks oli tegemist üldse esimese teenistuskohaga. 2-7 aastat olid ametis olnud 17, 8-15 aastat 13 ning 16-36 aastat 11 pastorit (kaks tegutsesid kahes koguduses ning ühes koguduses oli tegu kindlalt köstriga). Neli pastorit olid uue kirjaviisi kasutusele võttes ametis olnud juba vähemalt 30 aastat: Kanepi Holst, Lihula Spindler (kumbki 30), Mihkli Schmidt (34) ja Kose Hörschelmann (36). Seega leidus igasuguse staažiga (ning vanusega, kuna enamasti oli staaž korrelatsioonis vanusega) pastoreid üsna võrdselt ning tegu ei olnud ainult noorte ametisse asuvate pastoritega.

3 Mihkli kogudus on arvatud Läänemaa alla. Kuigi 2/3 elanikest kuulus kihelkonna Liivimaa ossa, asus kirik Eestimaa osas. 
1844 läks uuele kirjaviisile üle neli kogudust (Kuusalu, Jõelähtme, Haljala, Lüganuse), 1850. aastail kaks (Rapla, Karuse), 1860. aastail neli (Lääne-Nigula, Ridala ning kaks esimest Liivimaal - Pöide, Tarvastu), 1870.-1879. aastani 16 (10 Liivi-, 6 Eestimaal), 1880.-1889. aastani 47 (24 Liivi-, 23 Eestimaal), 1890 üks Liivimaa ja 1891 kaks Eestimaa kogudust. Seega algas Eestimaal uuele kirjaviisile üleminek oluliselt varem ning see on selgelt Ahrensi mõju, mida sageli on peetud pastorkonnas praktiliselt olematuks (Vilbaste 1961: 13, 15). Liivimaal algas üleminek alles rahvusliku liikumise alguses, olles sellest ajast alates tempo poolest Eestimaaga võrdne.

Kõige enam mindi uuele kirjaviisile 1880. aastal (8 kogudust - 4 Liivi-, 4 Eestimaal) ja 1881. aastal (10 kogudust - 7 Liivi-, 3 Eestimaal). Enamasti ei olnud nende puhul tegu vastsete pastoritega, vaid neid olid tõenäoliselt mõjutanud juba toimunud kirjaviisivahetus trükisõnas (sh vaimulikus kirjanduses) ning võimalikud arutelud sinoditel.

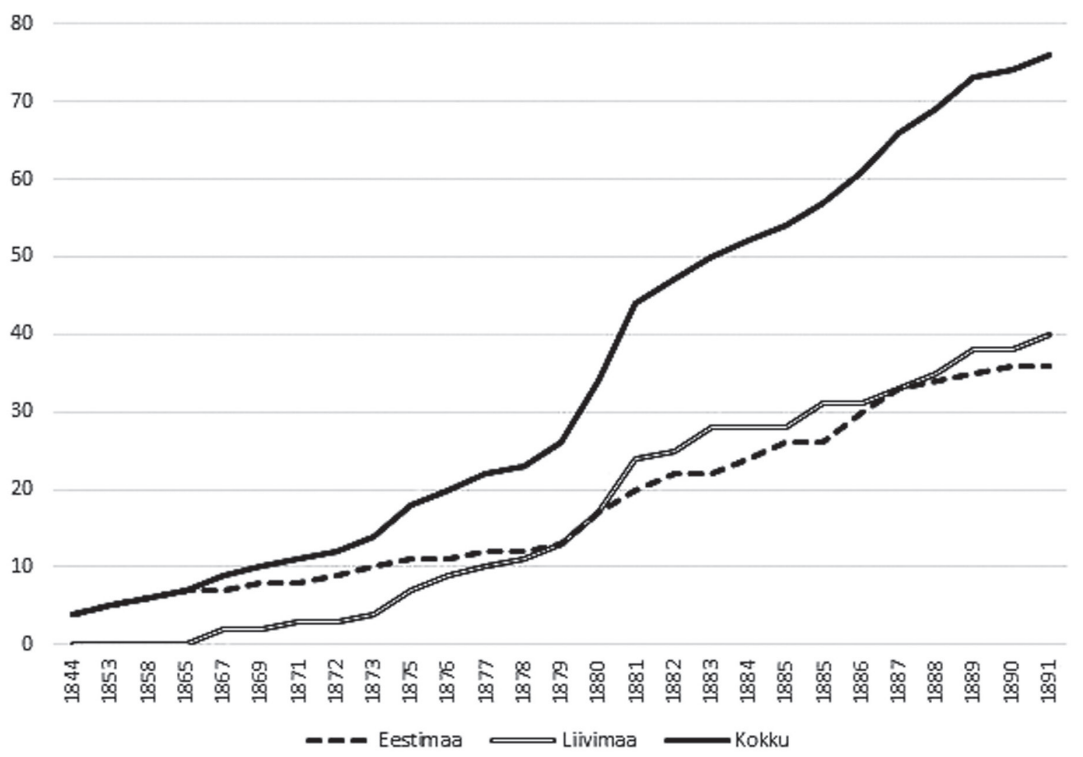

Joonis. Kirjaviisi vahetanud koguduste üldarv (analüüsitud 110 kogudust) 


\section{Pastorite rahvus ja kirjaviis}

Ühiskondlike muutuste tõttu hakkas kasvama eestlastest pastorite hulk. Seetõttu pakub huvi jälgida, kas olid seotud eesti rahvusest pastorite ametisse asumine ning kirjaviisi muutus.

Eesti rahvuse kindlakstegemine on alati olnud seotud raskustega, kuna veel XX sajandi algulgi toimus ümberrahvustumine eelkõige saksa, kohati ka vene rahvusesse sulanemise kaudu ning rahvuslik enesemääramine oli kõikuv. Väga paljud baltisakslastena tuntud inimesed olid tegelikult vähemalt osaliselt eesti päritolu (nt Masingid), kuid neid ei saa lugeda eestlasteks rahvuse (identiteedi), vaid ainult etnilise päritolu poolest. Praeguse teema puhul on olulised vaid need Eestis tegutsenud pastorid, kes tunnistasid ennast eestlasteks ${ }^{4}$, ning ei mängi rolli need, keda vaid päritolult võib eestlasteks lugeda, kui sedagi (nt Karjahärm, Sirk 1997: 34-35, 56 mainitud Janter, Kentmann, Masing, Normann, Willingen). Eestlastest abipastoreid pole analüüsitud.

Esimeseks ennast eestlaseks (mitte küll rahvuslaseks) pidanud pastoriks Eestis võib tinglikult lugeda Georg Theoli (1856-1867 Äksis). Tema uut kirjaviisi kasutama ei hakanud - Liivimaal ei teinud seda tema eluajal ka teised. Kuigi ta leidis, et ma kele kirjutamine Soomlaste visi järrele õigem on, kui meie vanna viis, arvas ta olulisemaks rahva kätte sedda visi jätta, kelle järrele keik nende ramatud on kirjutud ja trükkitud (Kask 1970: 209).

Järgmise eestlasena sai pastoriametisse Wilhelm Eisenschmidt (1870-1922 Tartu Peetri koguduses). Esimesel ametiaastal kasutas ta üldiselt vana kirjaviisi (Michel, Lena, Mina, Lina), kuid esines juba ka segastiili (Jüri ja Jürri, Mari ja Marri). Mõni uue kirjaviisi nimi kinnistus peagi, osa lisandus mõne aasta pärast, kuid väga tugevat segastiili ning ebaühtlust ka samade nimede kirjutamisel harrastas ta ametiaja lõpuni.

August Westrén-Doll (1871-1876 Mustjalas, ühtlasi 1875-1876 Kärlal, 1876-1909 Viljandi Pauluse koguduses) ei olnud küll kõiges rahvusliku liikumise pooldaja, näiteks algul toetas ta Aleksandrikooli liikumist, pärast oli selle aktiivne vastane (Kruus 1939: 63), kuid ometi võttis ta puhta uue kirjaviisi kasutusele 1875. aastal Mustjala ja ka tema hooldatavas Kärla koguduses ehk kohe pärast uue kirjaviisi võidulepääsu trükisõnas. Seda juhtumisi samal aastal, mil Liivimaa sinodil otsustati kõik eestlaste

\footnotetext{
${ }^{4}$ Aluseks on võetud Riho Saardi andmed (2000: 368-369 jm).
} 
rahvuslikud püüded tingimusteta hukka mõista (Saard 2000: 39), kuigi Doll töötas tollal veel Saaremaa konsistooriumiringkonnas.

Järjepidev ei olnud algul uues kirjaviisis ka selle suur propageerija, neljas eestlasest pastor Jakob Hurt (1872-1880 Otepääl). Algul kasutas ta tugevat segastiili, mõne aasta pärast pigem uut kirjaviisi, aga sugugi mitte puhast. Kuigi 1874. a Liivimaa sinodil esines Hurt eesti keele kaitseks (Saard 2000: 39), valdas ta ise uut kirjaviisi püsivamalt alles 1875. a lõpus, millest alates ei kohta enam veel sama aasta suvel kasutatud nimekuju Peter, mis on asendunud nimega Peeter (seda kasutas ta paralleelselt varemgi). Samas jäi tal mõni nimi vahelduvalt kasutusse (Michel ja Mihkel) Otepääl tegutsemise lõpuni. Huvitav on märkida, et Hurda eel, ajal ja järel (kokku 68 aastat) tegutses Otepää köstrina Anveldt, kes oli tuntud oma saksikusega (Põldmäe 1968: 400). Siinse teema puhul kinnitab seda näide, kus ta pastor Kauzmanni poolt 1870 meetrika algeksemplaris kirja pandud nimest Mihkel on meetrikat ümber kirjutades korduvalt teinud nime Michel. Sama tegi ta Hurda originaalmeetrika ümberkirjutamisel, näiteks 1874. a sissekannetes kirjutas ta Hurda kirjapandud nimede Jüri, Mari, Juhan, Tamm asemel Jürri, Marri, Johan, Tam. Muide, Hurda ja Anveldti (samuti järgmise pastori Sperrlingki) käekiri on äravahetamiseni sarnane, sissekannete võrdlemise teeb keerukamaks ka see, et Hurt on oma tähekujusid sageli varieerinud.

Otepää järgmine pastor oli eestlane Sperrlingk (ametis 1881-1905), kes kasutas segakirjaviisi, mis 1890. aastaiks oli uue kirjaviisiga sarnasem kui 1880. aastail. Temagi ei hiilanud oma ametis eestimeelsusega (Põldmäe 1968: 396-398).

Ajaliselt viienda eestlasest pastorina astus ametisse esimene selline Eestimaal - Türi pastor Kurrikoff (1875-1891). Tema võttis kohe tarvitusele puhta uue kirjaviisi.

Saardi (2000: 367) andmetel oli ajavahemikul 1875-1890 Tartu ülikooli usuteaduskonda immatrikuleeritud 76 eestlasest 66 pärit Liivimaalt, 9 Eestimaalt ning üks Venemaalt. Näha on Liivimaa oluliselt suurem osakaal nagu kogu rahvuslikus liikumises üldiselt.

1891. aastaks, kuni üle Eesti on võimalik jälgida kirjaviisi kasutamist meetrikaraamatutes, oli Liivimaal ametisse astunud 17 eestlasest pastorit, Eestimaal vaid kolm. Liivimaa pastoritest kolm võtsid esimesena ja kohe ametisse asudes uue kirjaviisi kasutusele (Jürmann, Koik, Punga), üks võttis selle esimesena kasutusele pärast mõnda aega (Westrén-Doll), viis 
jätkasid selle kasutamist (Kerg, Ederberg, Undritz, Reiman, Lipp), kolme kohta pole võimalik andmeid saada, kuna nende käekirjaga peetud meetrikaid pole (Kallas, Bergmann, Rennit), üks läks segakirjaviisi kaudu paari aasta pärast uuele üle (Hurt), üks läks algul tagasi segakirjaviisile ning paari aasta pärast uuele (Pielberg), üks läks tagasi ja jäi segakirjaviisile (Sperrlingk), kaks jäid segakirjaviisi kasutajaks (Theol, Eisenschmidt). Seega üheksal pastoril polnud uue kirjaviisiga probleeme (tõenäoliselt võib nendele lisaks arvata ka Bergmanni, kelle kohta andmeid pole), kolm aga selle juurde ei jõudnudki. Eestimaa kolmest pastorist kaks võtsid selle esimesena kasutusele (Kurrikoff, Pallon), üks jätkas kasutamist (Willberg).

Paavo Annuse (1996: 26-27) andmetel toimus 1890. aastail pastorkonnas suur rahvuslik muutus. Samavõrra, kui vähenes saksa pastorite perest pärit ametis olevate pastorite osakaal, suurenes talupojaperedest (kes üldjuhul olid eestlased) pastorite osakaal. Kuna kirjaviisivahetus toimus kirikuraamatutes aga enamasti 1880. aastail või konservatiivsemate pastorite puhul alles XX sajandil, ei olnud päris õige Hurda arvamus, kes 1865 Johann Kölerile kirjutas, et [kiriku] õpetajad ise mitte ainult midagi keelelise edu heaks ei tee, vaid suurem osa pealegi kindlasti selle vastu on ja .. paranduse maksmapanemisele takistusi teevad. Hurt leidis, et pastorite mõju aga on väga tuntav ja keelereform (mitte ainult õigekirjas) ei saa mitte enne läbi tungida, kui pastorite hulka rahvuslisi ollusi tuleb, .. kes uuendamise ja edasiarendamisetöö oma peale võtavad (Köler-Hurt 1911: 138). Köler oma vastuses Hurdale kinnitas seda: Nagu uuenduse algatuse eest üksikutele pastoritele tänu võlgnetakse, nii on ka suurem osa hingekarjaseid selle vihasemad vastased (Köler-Hurt 1911: 141). Läks veel viisteist aastat aega ning pastorid, olenemata oma rahvusest ning ametis oldud aja pikkusest, hakkasid uuele kirjaviisile üle minema enne, kui eestlaste osakaal pastorkonnas oluliselt suurenes. 64 koguduses 76st läksid 1891. aastaks uuele kirjaviisile esimesena üle just sakslastest (mõnel üksikul juhul saksastunud eestlastest) pastorid. 


\section{Uue kirjaviisi ja nimede teema pastorkonnas XIX-XX sajandi vahetusel}

Eestimaa provintsiaalsinod oli uue kirjaviisi vastu viimase võimaluseni. Praostkondade sinodid olid aga sageli seda pooldavad, nagu Viru praostkonna puhul (1871) mainitud. 1881. a sinod manitses uue kirjaviisi kasutuselevõtmisega mitte kiirustama, kuigi Järva praostkond oli teinud ettepaneku aabits ja piiblilood trükkida järgmisel korral uues kirjaviisis ning Harju, Viru ja Järva praostkonnas õpetati 288 koolis uues, 114-s aga vanas kirjaviisis (Paul 1999: 589).

1886 ilmus tartukeelne uus testament vanas kirjaviisis, kuigi aasta varem olid Viljandimaa eestlastest pastorid Bergmann, Westrén-Doll ja Jürmann hakanud seda uude kirjaviisi ümber panema. Uues kirjaviisis tallinnakeelne uus testament valmis 1886, kuid ilmus trükist 1888. Seejärel võttis Rapla praost Malm enda peale piibli panemise uude kirjaviisi ning see ilmus 1889 (Paul 1999: 591-593).

Seda, et tõenäoliselt piibli ilmumine uues kirjaviisis mõjutas vähemalt osa pastoreid, iseloomustab ehk ka Simuna köster Normanni käsiraamatu eessõna aastast 1873: Ni kaua kui se [piibel - FP] muutmata wannal wisil meie käes on, pean weel ikka wanna kirjutamise wisist kinni (Kask 1958: 178).

Uue kirjaviisi küsimust just nimede kirjutamisel arutati Eestimaa konsistooriumis näiteks 1892. Haljala pastor Willingen kirjutas 1891 konsistooriumile oma murest, et tema eelkäija, Haljala pikaaegne (1838-1880) pastor Striedter kirjutas saksakeelsed perekonnanimed häälduspäraselt ehk nii, kuidas eestlane seda de facto hääldab. Probleemiks osutus Willingeni jaoks, et sisserännanute nimed olid nende saabumise kirikutähel teistmoodi kui Haljala kirikuraamatutes ning nii võisid ka õed-vennad olla erineva perekonnanimega. Ta tõi ka näiteid, et vahelduvad Pus ja Busch, Wreibus ja Freibusch, Perk ja Berg jne (EAA.1187.2.1871, L 1-1p).

Konsistoorium küsis seepeale praostkondade arvamust. Lääne-Harju praost Malm, kes oli kohe Rapla pastori ametisse asumisel oma kirikuraamatutes kasutusele võtnud uue kirjaviisi, kinnitas, et tema praostkonnas pole see küsimus asjakohane. Perekonnanimed, mis on kunagi talupoegadele pandud, erinesid Malmi hinnangul üsna vähe eesti keele grammatikast ja õigekirjutusreeglitest (EAA.1187.2.1871, L 3).

Malm puudutas oma vastuses veel üksikuid õigekirjutusküsimusi ning leidis, et kui uus kirjaviis tuli, hakkas mõni pastor kõhklematult 
muudatusi, mis eesnimesid puudutasid, ka perekonnanimedele laiendama. Tema ise jäi osaliselt vana kirjaviisi juurde. Suur osa rahvast aga, nimelt vallakirjutajad, olid Malmi sõnul juba ammu loobunud nimede ametlikust kirjapildist ja kirjutasid neid häälduse järgi, saades mõnikord niimoodi uue nime. Malm soovitas anda ametlikult loa eesti perekonnanimesid kirjutada soome ortograafia järgi ning neid nimesid, mis pole eesti päritolu ja mida teadmatusest teisiti kirjutatakse, uuesti õigesti kirjutama hakata (EAA.1187.2.1871, L 3p-4p).

Läänemaa praost Pezold pakkus välja, et aluseks võiks võtta praegu kirikuraamatutes kirja pandud nimed ning varasemad nimekujud sulgudesse lisada, et neid teaks omavahel kokku viia (EAA.1187.2.1871, L 5). Alutaguse praost Hunnius tõi näiteid oma koguduste nimeprobleemide kohta ja leidis, et pastor võib nimesid korrigeerida ning kui kõik perekonnaliikmed „korrumpeerunud” perekonnanime kannavad, ongi nimi samahästi kui muudetud (EAA.1187.2.1871, L 6-6p).

Ida-Harju praost Kentmann edastas oma pastorite teated, et neil sellist probleemi ei esine, aga tõi oma Kuusalu koguduse kohta näite, et seal on päris sagedad juhtumid, kus vallakirjades on perekonnal üks, kirikuraamatutes aga teine nimi. Ta soovitas noil puhkudel kirikuraamatutesse lisada märkuse ,vallakirjades on N. N. nime all“" (EAA.1187.2.1871, L 12).

Viru praost Hoffmann kirjutas, et tema Viru-Jaagupi koguduses on uute personaalraamatute kasutusele võtmisel (see toimus 1884. a paiku) need kirja pandud ,niinimetatud uues (Ahrensi) kirjaviisis“(EAA.1187.2.1871, L 13-13p).

Ka Liivimaal arutati seda küsimust. 1903. a seadis Saaremaa praostkonna sinod sisse lausa komisjoni eestlaste perekonnanimede õigekirjutuse korraldamiseks. Komisjon andis oma seisukoha, et kõik eestlaste eestikeelsed perekonnanimed tuleks kirjutada uues kirjaviisis, eestlaste muukeelsed (eelkõige saksakeelsed) aga vastava keele õigekirjareeglite järgi (EAA.5281.1.113).

Kärla pastor Kerg koostas sinodis üles võetud teema kohta referaadi eesti nimede (uue kirjaviisi kohaselt) õigekirjutusest kirikuraamatutes. Kerg oli talupoja poeg Tähtverest Tartumaalt, Kärla pastor 1878. aastast, ja võttis kohe kasutusele uue kirjaviisi. Ta esitas ka oma teesid uue kirjaviisi kasutamiseks (EAA.5281.1.113). Kerg oli igati aktiivne ühiskonnategelane ning kohaliku rahva elatustaseme parandaja. 
Toomas Paul (1999: 561) on leidnud, et kirik oleks võinud XIX sajandi keskel olla esimeste seas, kes läheb üle adekvaatsemale keele- ja kirjakasutusele, kuid tegelikult jäi talle osaks pool sajandit hiljem sellele tõrkudes alistuda. Pauli (1999: 583) hinnangul baltisakslastest vaimulikud ei taibanud üldse, millised pöördumatud muutused toimuvad. Nad elasid oma suletud maailmas ega suutnud uskuda, et see peatselt kokku variseb.

Nagu näha uue kirjaviisi kasutuselevõtust alles 1880. aastail, andsid pastorid tõesti lõpuks justkui vastumeelselt alla, varasemad kirjaviisivahetajad olid enamasti huvitatud keelest või vähemalt toetasid eestlaste rahvuslikku liikumist. Umbkaudu kolmandik jäi aga truuks vanadele (kuigi ebaühtlastele) traditsioonidele.

\section{Meetrikate nimekujude hilisem mõju}

Kui XIX sajandil ei olnud nimekandjal talupojal enamasti tähtis, kuidas täpselt tema nime kirjutati, siis XX sajandil hakati nimekirjutusele rohkem tähelepanu pöörama. 1926 sisse seatud riiklikes perekonnaregistrites ehk perekirjades võeti ametliku nime fikseerimisel aluseks inimese sünnisissekande nimekuju või usuvahetuse korral enne 1. juulit 1926 viimasel ristimisel või salvimisel antud nimi (Teder 1939: 20-21). Sageli oli see veel vanas kirjaviisis ning 1927 selgitas riigikohus, et see ei ole nime muutmine, vaid nime õigekirjutuslik parandamine. Kohtu seisukoha järgi olenes nimekandjast, kas kirjutada Leppik, Varri, Kalla või Lepik, Vari, Kala (Teder 1939: 23).

Perekonnaseisuametnikke manitseti, et vanas kirjaviisis nimede uude kirjaviisi ümberkirjutamine pole nime muutmine, vaid parandamine, sest on selge, et nimed nagu Maddis, Juhhan, Adu, Jan jne. on vigaselt kirjutatud ning ametnik peaks soovitama nimekandjal esitada nime õigekirjutusliku parandamise avaldus (Teder 1939: 28).

Teinekord vormistati selline nime parandamine siiski nime muutmisena, sest sel juhul (eelkõige mõeldi selle all eestistamist) oli perekirjade avamine (mis pidi muutuma igale Eesti kodanikule kohustuslikuks) tasuta. Leidus aga ka perekonnaseisuametnikke, kes nende juurde tulnud kodaniku nime parandasid tõenäoliselt pikema jututa uude kirjaviisi.

Tavakodanik muidugi ei olnud kindel, kuidas nime kirjutada, seega seadustusid ka 1930. aastail, kui enamik perekirju koostati, vanas 
kirjaviisis ees- ja perekonnanimed. Perekirjade põhjal anti välja perekonnaseisutunnistusi ning nõukogude ajal juba ka passe.

\section{Kokkuvõte}

Pärast uue kirjaviisi loomist 1843. aastal pastor Ahrensi poolt ei hakanud see sugugi kiirelt levima. Algul kasutas seda vaid neli pastorit Eestimaal, kus Ahrens sinoditel korduvalt oma kirjaviisi toetuseks sõna võttis. Väikest mõju avaldas ka tema grammatika teise trüki avaldamine aastal 1853 . Seega Ahrens ei jäänud praktikas oma uue kirjaviisiga ka pastorkonnas päris üksi, nagu on arvatud. Liivimaa pastorid jäid tollal siiski veel uuest kirjaviisist puutumata.

Ilmalik kirjandus (sh ajakirjandus) võttis uue kirjaviisi kiiremini omaks ning moodustas ülekaalu 1875. aastaks. See oli seotud rahvusliku liikumisega, mis mõjutas mõningal määral ka baltisaksa pastoreid uut kirjaviisi kasutusele võtma. Kuna liikumine oli Liivimaal tugevam, tekkisid seal esimesed uuele kirjaviisile üleminejad just 1860. aastate teisel poolel, Eestimaast paarkümmend aastat hiljem.

Kuna ka vaimulikud raamatud hakkasid ilmuma uues kirjaviisis (piibel aastal 1889), mõjutas see pastoreidki lõpuks uut kirjaviisi oma meetrikaraamatutes kasutusele võtma. Kõige suurem üleminekulaine nii Eesti-kui ka Liivimaal oli aastail 1880-1881. Siiski oli 1881. a lõpuks uuele kirjaviisile üle läinud vaid 44 koguduse pastorid 110 analüüsitust. Järgmise kümne aasta jooksul tegi seda veel ligi kolmandik (32 kogudust), ulatudes 1891. aastaks 76ni, kuid ligi kolmandik (34 kogudust) jäi hiljemgi vana või segakirjaviisi juurde. 1892. aastast peeti meetrikaraamatuid enamasti kirillitsas, mis teeb hilisemate aastate analüüsi võimatuks. Nähtavasti põhjustas osaliselt vana kirjaviisi juurde jäämist peale alalhoidlikkuse ka eesti kirjakeele reeglite ebapiisav tundmine ning reeglite pikk ühtlustusaeg. Ainult Viljandimaal läksid uuele kirjaviisile üle kõik kogudused. Väikseim oli kirjaviisivahetus Võrumaal, seda nähtavasti lõunaeesti keele tõttu, mis kasutas trükisõnas valdavalt vana kirjaviisi.

Olulisem rahvuslik muutus pastorkonnas eestlaste osakaalu suurenemisena 1890. aastail jäi valdavast kirjaviisivahetusest hilisemasse aega. Ka kõik eestlastest pastorid ei võtnud uut kirjaviisi kasutusele, seega pastorite rahvuslik päritolu kirjaviisivahetust ei mõjutanud. 


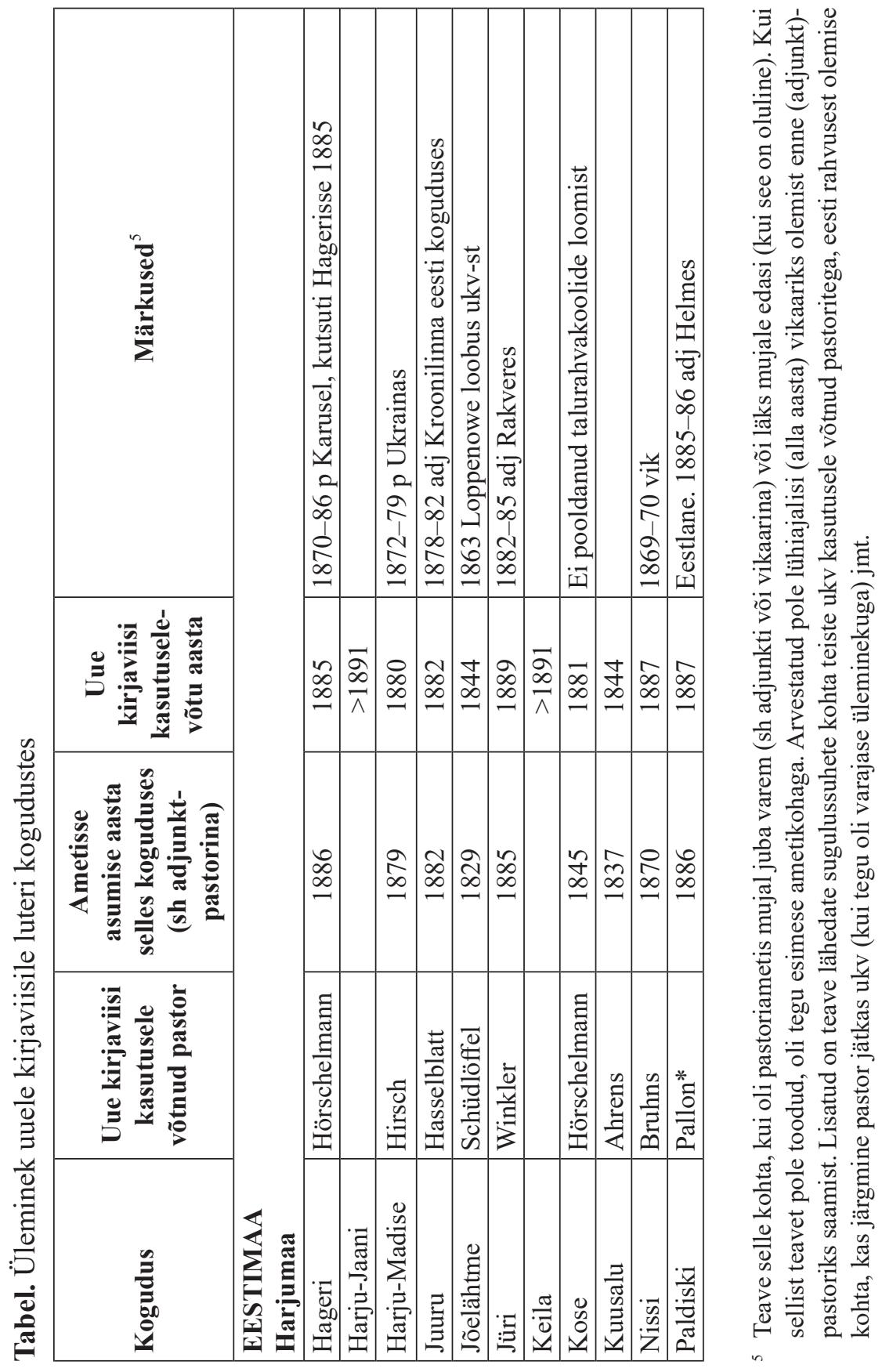




\begin{tabular}{|c|c|c|c|c|c|c|c|c|c|c|c|c|c|c|c|c|c|}
\hline 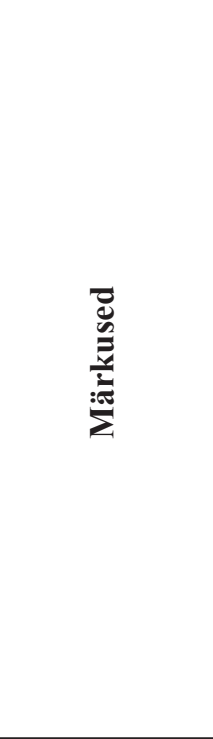 & 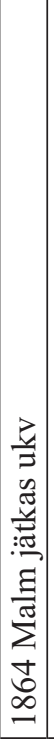 & 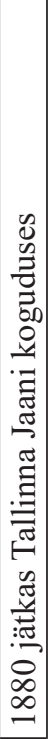 & & & & 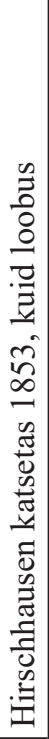 & & & 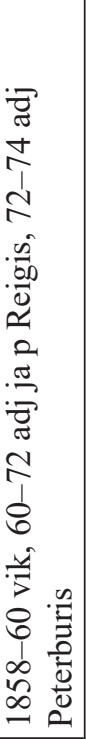 & 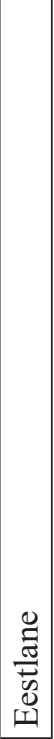 & & 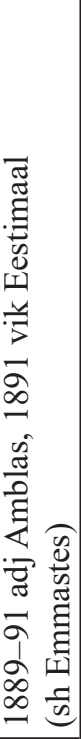 & 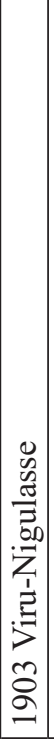 & 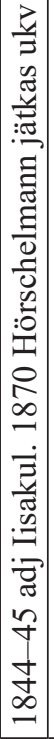 & 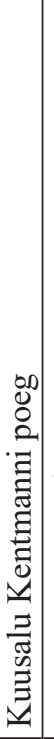 & 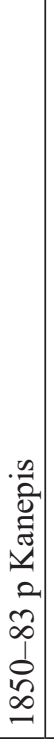 & \\
\hline 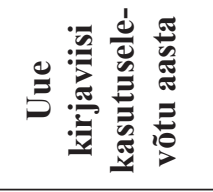 & $\begin{array}{l}* \\
* \\
\cdots \\
\infty \\
\infty \\
-1\end{array}$ & $\hat{\infty}$ & & $\frac{2}{\infty}$ & $\frac{\sqrt{2}}{\curvearrowright}$ & $\begin{array}{l}\vec{\partial} \\
\stackrel{\wedge}{\wedge}\end{array}$ & $\begin{array}{l}\vec{\partial} \\
\stackrel{\wedge}{\wedge}\end{array}$ & $\begin{array}{l}\bar{\sigma} \\
\bar{\wedge}\end{array}$ & \begin{tabular}{l}
$*$ \\
\multirow{6}{*}{} \\
$\infty$ \\
$\infty$ \\
-
\end{tabular} & $\begin{array}{l}n \\
\infty \\
-\end{array}$ & & ळ & $\begin{array}{l}\infty \\
\infty \\
\infty \\
-\end{array}$ & $\begin{array}{l}\infty \\
\infty \\
\infty \\
-\end{array}$ & $\begin{array}{l}0 \\
\infty \\
\infty \\
-\end{array}$ & $\begin{array}{l}+ \\
\infty \\
\infty\end{array}$ & \begin{tabular}{l}
$*$ \\
$*$ \\
\multirow{*}{*}{} \\
$\infty$ \\
- \\
\end{tabular} \\
\hline 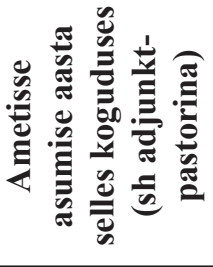 & $\hat{\infty}$ & $\begin{array}{l}\stackrel{0}{\pi} \\
\infty\end{array}$ & & $\hat{\infty}$ & & & & & $\underset{\infty}{\Delta}$ & $\begin{array}{l}n \\
\infty \\
-1\end{array}$ & & నิ & $\begin{array}{l}\infty \\
\infty \\
\infty \\
-\end{array}$ & 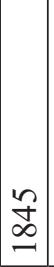 & $\begin{array}{l}0 \\
\infty \\
\infty \\
-\end{array}$ & $\begin{array}{l}\infty \\
\infty \\
\infty\end{array}$ & $\begin{array}{l}N \\
\infty \\
\infty\end{array}$ \\
\hline 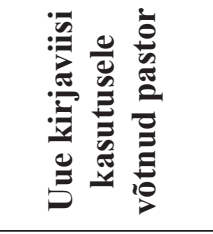 & 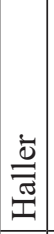 & 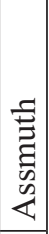 & & 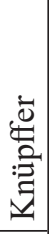 & & & & & 咅 & 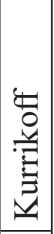 & & 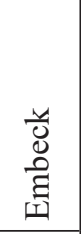 & 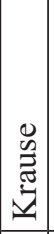 & 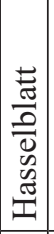 & 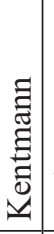 & $\begin{array}{l}\frac{\tilde{a}}{0} \\
\underline{I}\end{array}$ & 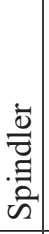 \\
\hline 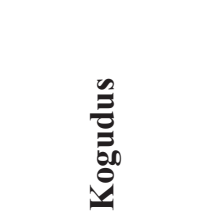 & $\left|\begin{array}{c}\frac{\pi}{\pi} \\
\vec{A} \\
\tilde{a}\end{array}\right|$ & $\stackrel{\overrightarrow{0}}{\tilde{2}}$ & 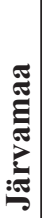 & $\begin{array}{l}\frac{\pi}{0} \\
\frac{\Xi}{\mathbb{Z}}\end{array}$ & 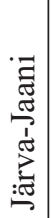 & 兽 & $\begin{array}{l}\overrightarrow{\vec{D}} \\
\ddot{D} \\
\ddot{U}\end{array}$ & 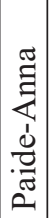 & $\begin{array}{l}\Xi \\
\\
0 \\
0\end{array}$ & $\begin{array}{l}: \Xi \\
: \Xi\end{array}$ & : & 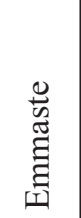 & 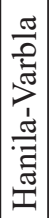 & 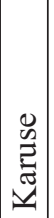 & 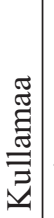 & $\underset{\mathfrak{\Xi}}{\stackrel{\widetilde{U}}{\Xi}}$ & 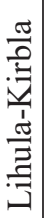 \\
\hline
\end{tabular}




\begin{tabular}{|c|c|c|c|c|c|c|c|c|c|c|c|c|c|c|c|}
\hline 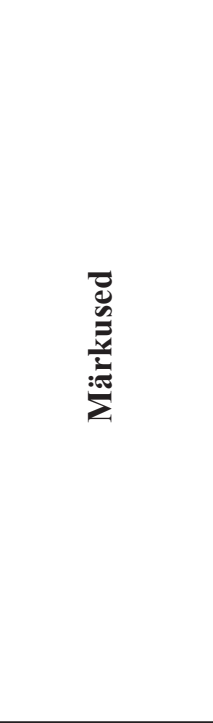 & 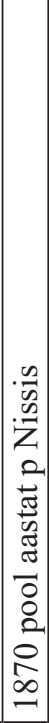 & 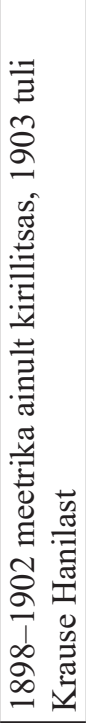 & & & 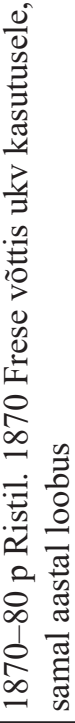 & 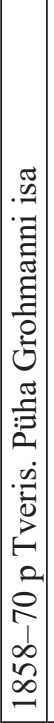 & & & & 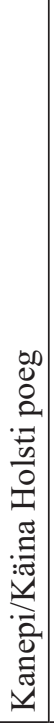 & 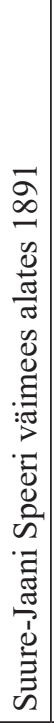 & 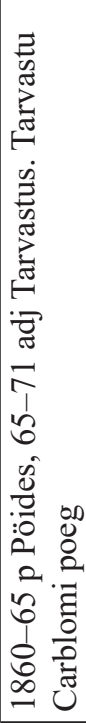 & 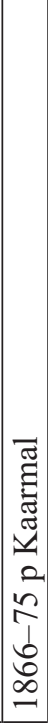 & 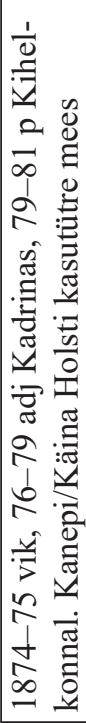 & \\
\hline 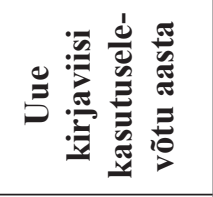 & $\underset{\infty}{\infty}$ & 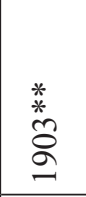 & $\begin{array}{l}\vec{\partial} \\
\stackrel{\wedge}{\wedge}\end{array}$ & & $\begin{array}{l}* \\
\stackrel{*}{\infty} \\
\infty \\
-\end{array}$ & $\begin{array}{l}* \\
* \\
* \\
\infty \\
\infty \\
-\end{array}$ & $\begin{array}{l}\vec{\Omega} \\
\bar{\wedge} \\
\wedge\end{array}$ & $\begin{array}{l}\stackrel{*}{*} \\
\stackrel{\infty}{0} \\
\infty \\
- \\
\end{array}$ & & $\begin{array}{l}* \\
\stackrel{*}{*} \\
\infty \\
\infty \\
-\end{array}$ & $\begin{array}{l}* \\
\text { * } \\
\sigma\end{array}$ & $\begin{array}{l}* \\
\stackrel{*}{*} \\
\infty \\
\infty \\
\end{array}$ & $\begin{array}{l}9 \\
\infty \\
\infty \\
\end{array}$ & $\begin{array}{l}\infty \\
\infty \\
\end{array}$ & $\begin{array}{l}\text { * } \\
\text { *̋ } \\
\text { ळ } \\
\text { - }\end{array}$ \\
\hline 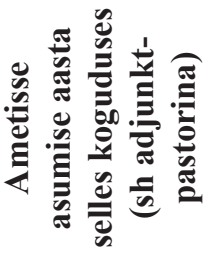 & 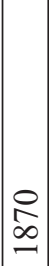 & & & & $\begin{array}{l}\infty \\
\infty \\
\infty\end{array}$ & $\begin{array}{l}0 \\
\infty \\
\infty\end{array}$ & & $\hat{\infty}$ & & $\begin{array}{l}\infty \\
\infty \\
\infty\end{array}$ & $\begin{array}{l}2 \\
\infty \\
\infty\end{array}$ & $\bar{\infty}$ & $\underset{\infty}{\infty}$ & $\begin{array}{l}\infty \\
\infty\end{array}$ & $\stackrel{\infty}{\infty}$ \\
\hline 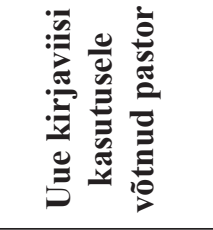 & 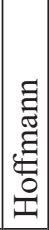 & & & & 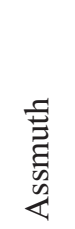 & 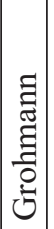 & & 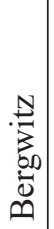 & & $\begin{array}{l}\frac{\pi}{n} \\
0 \\
\pm\end{array}$ & $\begin{array}{l}\Xi \\
\stackrel{\Xi}{0} \\
\varrho\end{array}$ & $\frac{\Xi}{0}$ & $\mid \begin{array}{l}7 \\
0 \\
0 \\
0 \\
0 \\
000 \\
0 \\
0 \\
0\end{array}$ & 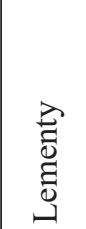 & 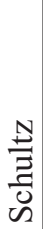 \\
\hline 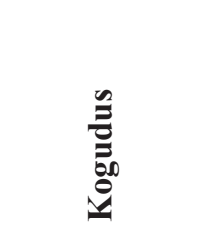 & 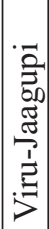 & 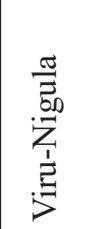 & 效 & $\stackrel{\Xi}{\stackrel{\Xi}{\Xi}}$ & 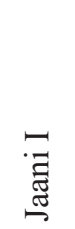 & 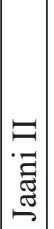 & 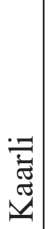 & 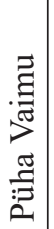 & 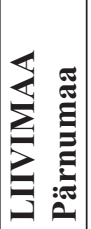 & $\begin{array}{l}\vec{Z} \\
\stackrel{Z}{Z} \\
\stackrel{Z}{Z}\end{array}$ & 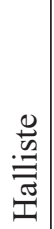 & 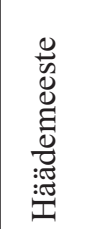 & $\mid \begin{array}{l}\overrightarrow{\tilde{v}} \\
\vec{z} \\
\vec{z} \\
\underline{v}\end{array}$ & 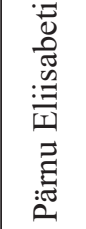 & 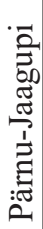 \\
\hline
\end{tabular}




\begin{tabular}{|c|c|c|c|c|c|c|c|c|c|c|c|c|c|}
\hline & 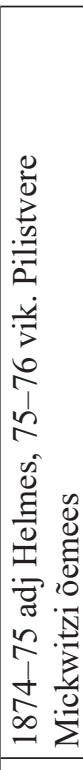 & 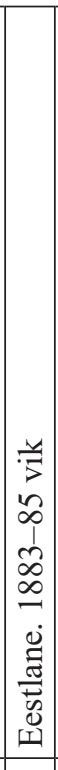 & & & 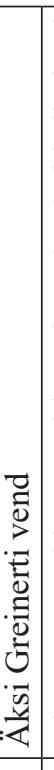 & 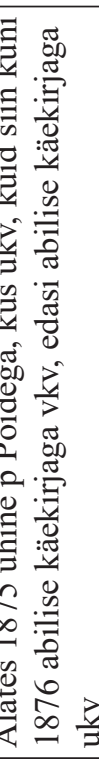 & 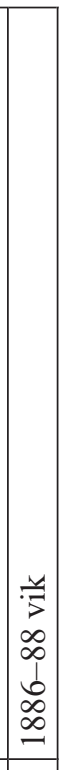 & 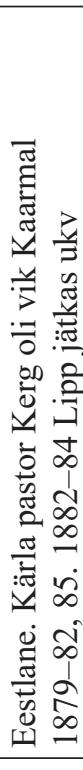 & 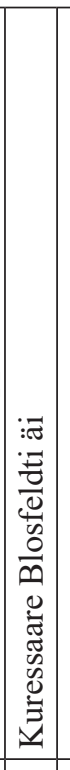 & & 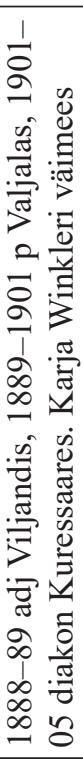 & 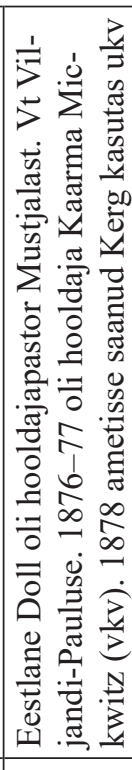 & 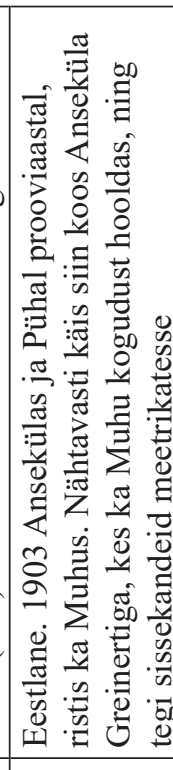 \\
\hline & $\underset{\infty}{\stackrel{\infty}{\infty}}$ & $\mid \begin{array}{l}n \\
\infty \\
\infty \\
-1\end{array}$ & $\begin{array}{l}* \\
\stackrel{*}{*} \\
\stackrel{2}{\infty} \\
\infty \\
\end{array}$ & & 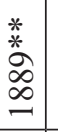 & $\stackrel{0}{\infty}$ & 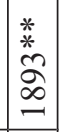 & $\begin{array}{l}\infty \\
\infty \\
\infty\end{array}$ & $\begin{array}{l}* \\
\stackrel{*}{*} \\
\infty \\
\infty \\
\infty \\
\end{array}$ & $\begin{array}{l}\infty \\
\infty \\
\infty \\
\infty\end{array}$ & $\stackrel{2}{2}$ & $\stackrel{\substack{\infty \\
\infty}}{\underline{\infty}}$ & $\stackrel{\text { }}{\varrho}$ \\
\hline & $\underset{\infty}{\infty}$ & $\mid \begin{array}{l}n \\
\infty \\
\infty \\
-1\end{array}$ & $\begin{array}{l}0 \\
0 \\
0 \\
\end{array}$ & & $\begin{array}{c}\stackrel{\infty}{\infty} \\
\infty \\
\end{array}$ & $\begin{array}{l}\frac{0}{0} \\
: 0 \\
0 \\
5 \\
\end{array}$ & $\begin{array}{l}\infty \\
\infty \\
\infty \\
-\end{array}$ & $\underset{\hat{\infty}}{\stackrel{\Omega}{-}}$ & $\begin{array}{l}\mathbf{0} \\
\stackrel{0}{-}\end{array}$ & $\begin{array}{c}\mathcal{D} \\
\infty \\
\stackrel{\infty}{-}\end{array}$ & $\bar{\varrho}$ & $\stackrel{n}{\infty}$ & $\stackrel{+}{\Delta}$ \\
\hline & 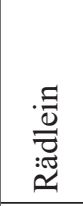 & 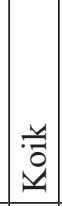 & 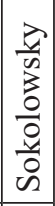 & & 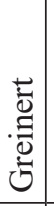 & $\frac{\bar{s}}{\frac{5}{0}}$ & $\begin{array}{l}\overrightarrow{\tilde{s}} \\
\frac{\vec{m}}{3} \\
\vec{z}\end{array}$ & $\stackrel{5}{\overrightarrow{0}}$ & 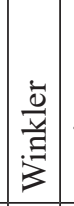 & 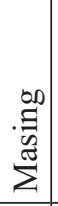 & 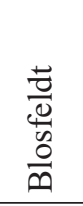 & 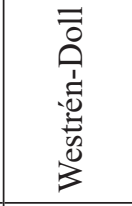 & $\frac{\vec{E}}{\mathbb{J}^{2}}$ \\
\hline & $\stackrel{0}{\circ}$ & 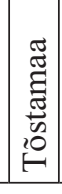 & $>$ & 离 & 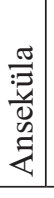 & 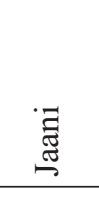 & \begin{tabular}{|l|} 
渮 \\
: \\
\end{tabular} & 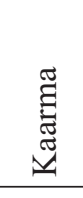 & 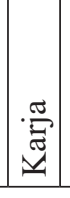 & 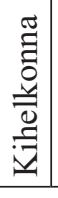 & 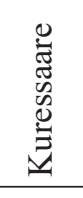 & 漓 & $\frac{\vec{z}}{\Sigma^{2}}$ \\
\hline
\end{tabular}




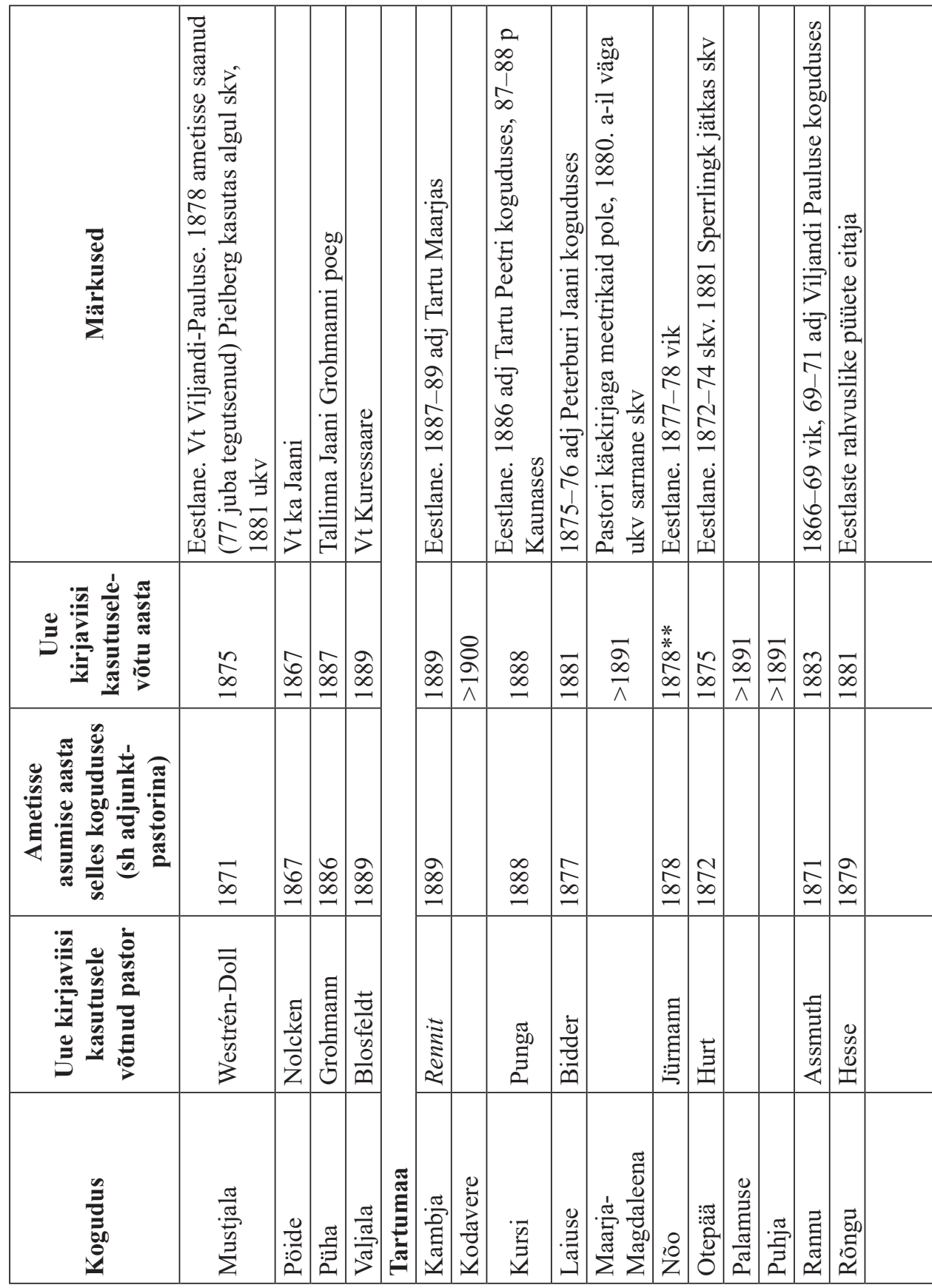




\begin{tabular}{|c|c|c|c|c|c|c|c|c|c|c|c|c|c|c|}
\hline 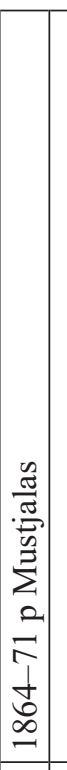 & & 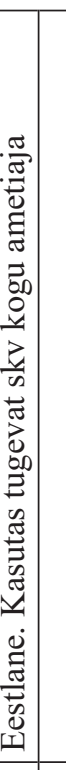 & 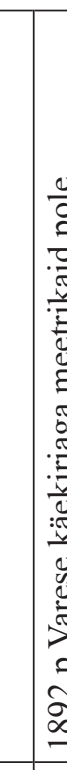 & 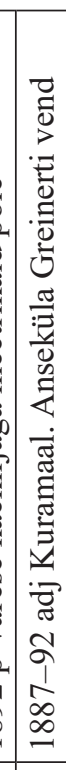 & & 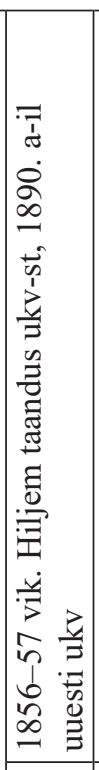 & & 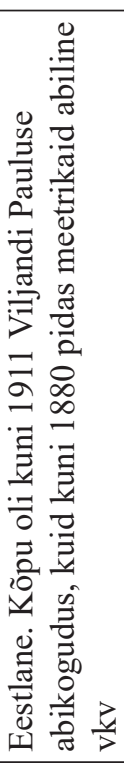 & 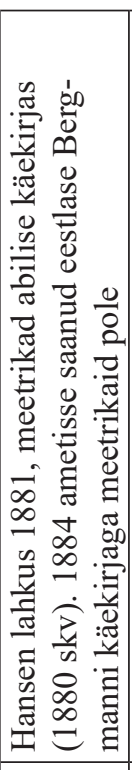 & 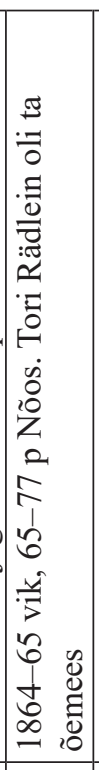 & 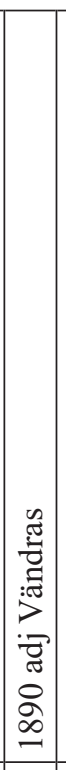 & $\begin{array}{l}y \\
5 \\
0 \\
0 \\
0 \\
0 \\
\infty \\
-\end{array}$ & 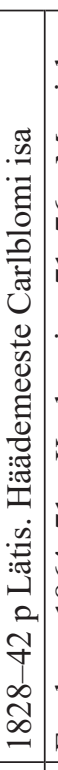 & 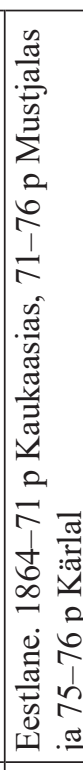 \\
\hline $\begin{array}{l}\hat{\infty} \\
\infty \\
\infty \\
\end{array}$ & 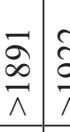 & 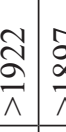 & 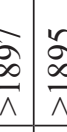 & $\underset{\stackrel{*}{*}}{\stackrel{*}{\tilde{\infty}}}$ & & 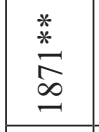 & $\begin{array}{l}\vec{\infty} \\
\infty \\
-\end{array}$ & $\begin{array}{l}\infty \\
\stackrel{\infty}{-} \\
\end{array}$ & $\begin{array}{l}\vec{\infty} \\
\infty \\
\end{array}$ & $\begin{array}{l}\mathscr{\infty} \\
\infty \\
\infty \\
-\end{array}$ & \begin{tabular}{l}
8 \\
$\infty$ \\
\hdashline
\end{tabular} & \begin{tabular}{c|}
$\stackrel{*}{*}$ \\
$\stackrel{*}{*}$ \\
$\infty$ \\
$\infty$ \\
-
\end{tabular} & \begin{tabular}{l}
$\stackrel{0}{\circ}$ \\
\hdashline \\
\end{tabular} & $\begin{array}{l}0 \\
\infty \\
\stackrel{\infty}{*}\end{array}$ \\
\hline $\begin{array}{l}\vec{\infty} \\
-\infty \\
\end{array}$ & & 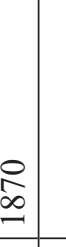 & & $\stackrel{\widetilde{\infty}}{\varrho}$ & & $\stackrel{\infty}{\infty}$ & $\begin{array}{l}\infty \\
\infty \\
\infty \\
-\end{array}$ & 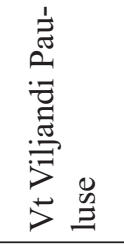 & & $\stackrel{\hat{\infty}}{\underline{\infty}}$ & $\begin{array}{l}\stackrel{0}{2} \\
\infty \\
-1\end{array}$ & $\begin{array}{l}0 \\
0 \\
\infty\end{array}$ & 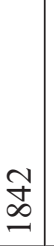 & $\begin{array}{l}0 \\
\infty \\
\infty\end{array}$ \\
\hline 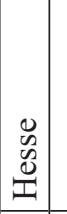 & & 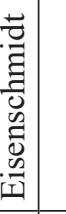 & & 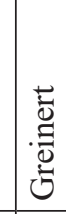 & & 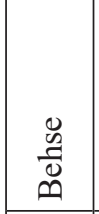 & 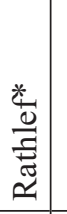 & 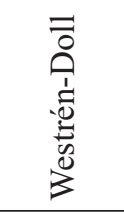 & & $\begin{array}{l}\frac{N}{3} \\
\frac{\sqrt{0}}{3} \\
\stackrel{2}{2}\end{array}$ & 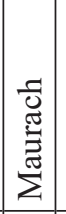 & $\begin{array}{c}\dot{\bar{D}} \\
\tilde{2}\end{array}$ & 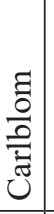 & 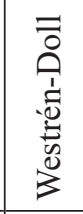 \\
\hline 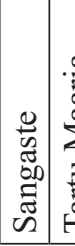 & 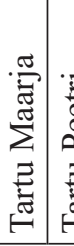 & |. & $\stackrel{2}{20}$ & : & $1>1$ & 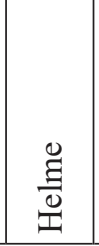 & 4 & 产 & 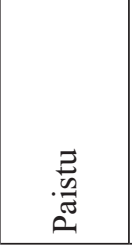 & 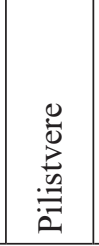 & 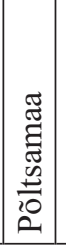 & 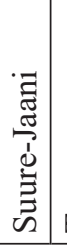 & 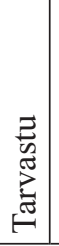 & 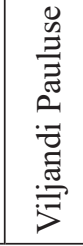 \\
\hline
\end{tabular}




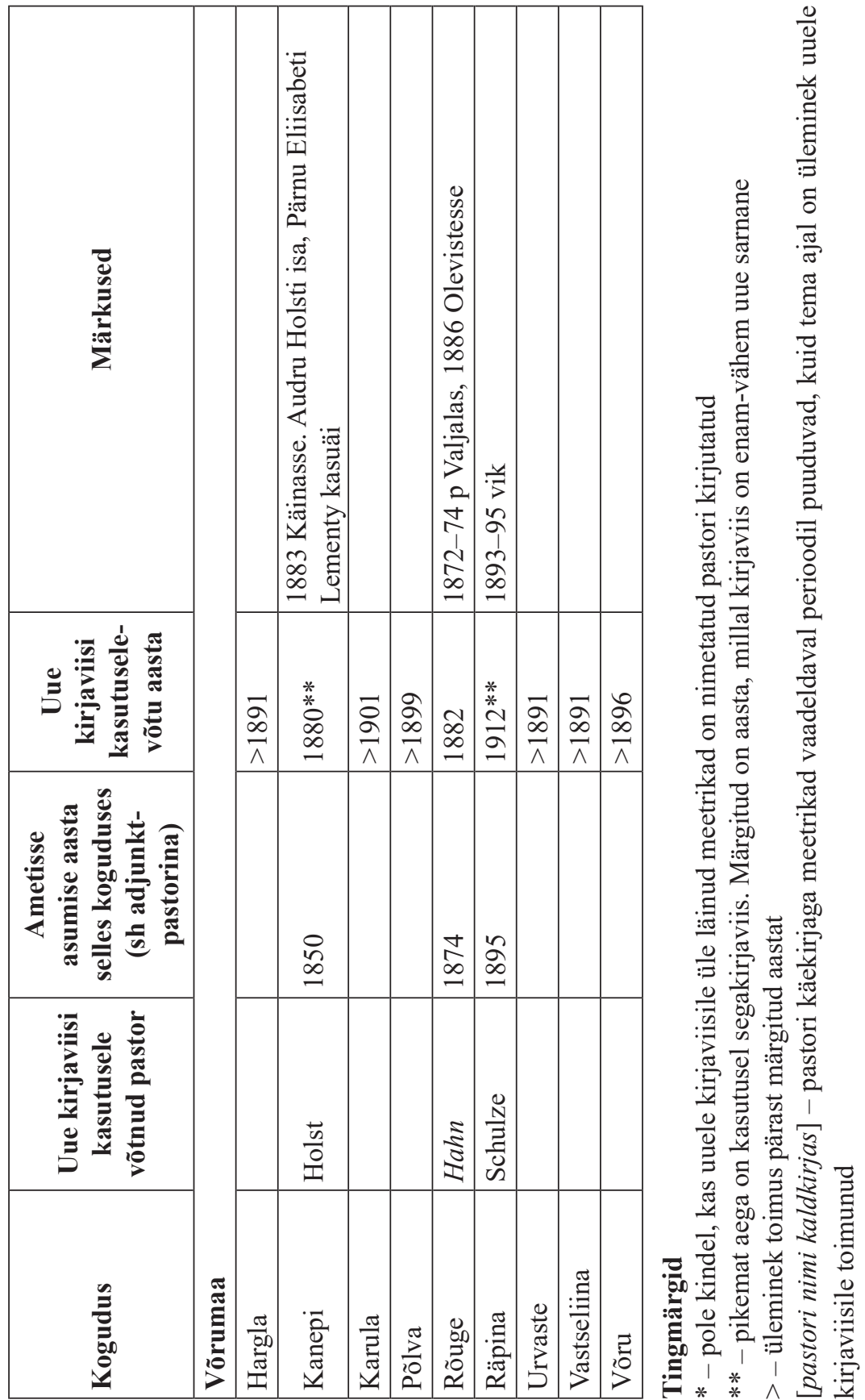




\section{Lühendid}

Ha - Harjumaa; Jä - Järvamaa; Lä - Läänemaa; Vi - Virumaa; Pä - Pärnumaa; $\mathrm{Sa}$ - Saaremaa; Ta - Tartumaa; Tln - Tallinn; Vl - Viljandimaa; Võ - Võrumaa; adj - adjunktpastor (kindla koguduse abipastor); $\mathrm{p}$ - pastor; skv - segakirjaviis; ukv - uus kirjaviis; vik - vikaarpastor (kindla koguduseta abipastor praostkonna või konsistooriumi juures); vkv - vana kirjaviis

\section{Kirjandus}

Aarma, Liivi 2007. Põhja-Eesti vaimulike lühielulood 1525-1885. Tallinn.

Aarma, Liivi 2011. Rapla koguduse õpetaja Eduard Pontus Haller. - EELK Rapla Maarja-Magdaleena koguduse leht 1, 2-3.

Ajalooline traditsioon $=$ Ajalooline traditsioon Tarvastu kihelkonna põhjapoolsest osast. Kogutud 1926. a. suvel. Linda Uudeküll. (= Ajalooline pärimus Eesti Kultuuriloolise Arhiivi kogudest.) Tartu: [Eesti Kirjandusmuuseum]. http://folklore.ee/radar/digi_pre.php?area=Tarvastu $\% 20$ p\%F5hjaosa (09.01.2018).

Annus, Paavo 1996. Luterliku kiriku vaimulikud Eestis 19. sajandi algusest kuni 1944. [Magistritöö käsikiri]. Tartu: Tartu Ülikooli Eesti ajaloo õppetool.

Arnek, Pille 2013a. Nimede kirjutamisest XIX sajandi hauatähistel ja meetrikaraamatutes. - Keel ja Kirjandus 6, 409-419.

Arnek, Pille 2013b. Eestikeelsed tekstid 19. sajandi Põhja-Eesti hauatähistel. Akadeemia 3, 465-492.

Henno, Kairit 2000. Poeglaste eesnimed Pöide eesti koguduse 1801.-1840. aasta sünniregistreis. - Emakeele Seltsi aastaraamat 44-45 (1998-1999). Tartu, 30-41.

Hurt, Jakob 1864. Lühikene õpetus õigest kirjutamisest parandatud wiisi. Tartu: Õpetatud Eesti Selts.

Hussar, Annika 2012. Muutused eesnimekasutuses XIX sajandil Martna ja Palamuse näitel. - Emakeele Seltsi aastaraamat 57 (2011). Peatoim. Mati Erelt. Tallinn: Teaduste Akadeemia Kirjastus, 35-59.

Hussar, Annika 2014. Eestlaste eesnimed 1900. aastal. - Emakeele Seltsi aastaraamat 60 (2014). Peatoim. Mati Erelt. Tallinn: Teaduste Akadeemia Kirjastus, 51-73. http://dx.doi.org/10.3176/esa60.03.

Jõelähtme 2014 = Jõelähtme kiriku kroonika II. Tõlk. Ülle Mölder, toim. Fred Puss. Tartu-Jõelähtme: Eesti Isikuloo Keskus, EELK Jõelähtme Püha Neitsi Maarja kogudus. http://maarjakirik.ee/web/userfiles/downloads/ kroonika2.pdf (06.01.2018).

Karjahärm, Toomas, Väino Sirk 1997. Eesti haritlaskonna kujunemine ja ideed 1850-1917. Tallinn: Eesti Entsüklopeediakirjastus. 
Kask, Arnold 1958. Võitlus vana ja uue kirjaviisi vahel XIX sajandi eesti kirjakeeles. (= Eesti NSV Teaduste Akadeemia Emakeele Seltsi toimetised 2.) Tallinn: Eesti Riiklik Kirjastus.

Kask, Arnold 1970. Eesti kirjakeele ajaloost. I-II. Tartu: Tartu Riiklik Ülikool. Kreutzwald 1976 = Kirjad Fr. R. Faehlmannile, D. H. Jürgensonile ja teistele. 1833-1866. (=Fr. R. Kreutzwaldi kirjavahetus I.) Tallinn: Eesti Raamat.

Kruus, Hans 1939. Eesti Aleksandrikool. Tartu: Noor-Eesti Kirjastus.

Köler-Hurt 1911 = Professor J. Köhleri ja J. Hurt'i kirjavahetus. - Eesti Kirjandus 4, 133-145.

Pastoren Estlands 1988 = Die Pastoren des Konsistorialbezirks Estland 1885-1919. Herausgegeben von Erik Amburger, bearbeitet von Helmut Intelmann .. [et al.]. (= Quellen und Studien zur baltischen Geschichte 11.) Köln, Wien: Böhlau.

Paul, Toomas 1999. Eesti piiblitõlke ajalugu. Esimestest katsetest kuni 1999. a-ni. (= Eesti Teaduste Akadeemia Emakeele Seltsi toimetised 72.) Tallinn.

Peegel, Juhan 1959. Nikolai Nolcken keelemehena ja folkloristina. - Emakeele Seltsi aastaraamat IV (1958). Tallinn: Eesti Riiklik Kirjastus, 48-69.

Prediger Livlands 1977 = Die evangelischen Prediger Livlands bis 1918. Begonnen von Paul Baerent. Im Auftrage der Baltischen historischen Kommission unter Mitarbeit von Erik Amburger, Helmut Speer. Herausgegeben von Martin Ottow, Wilhelm Lenz. Köln-Wien.

Põldmäe, Rudolf 1968. Jakob Pärna elust ja tegevusest Otepääl 1883-1908. Keel ja Kirjandus 7, 395-403.

Pärsik, Liisi, Taavi Pae 2011. Eesnimede piirkondlikud erinevused Eestis 1840. a-1. - Akadeemia 3, 511-536.

Rajandi, Edgar 1963a. Kaks praegust eelisnime. - Keel ja Kirjandus 2, 109-110.

Rajandi, Edgar 1963b. Nimevähesusest XVIII sajandi esimesel poolel. - Keel ja Kirjandus 3, 177-178.

Rajandi, Edgar 1963c. Elisabet(h) ja selle lühendid. - Keel ja Kirjandus 11, 690.

Rajandi, Edgar 1965. Made ja mõnda sellega seoses. - Keel ja Kirjandus 3, 179-180.

Rajandi, Edgar, Helmut Tarand 1966a. Perekonnanimedest ja nende uurimise ülesannetest. - Keel ja Kirjandus 4, 226-231

Rajandi, Edgar, Helmut Tarand 1966b. Meie perekonnanimede liigitamisest ja seletamisest. - Keel ja Kirjandus 7, 393-402.

Rajandi, Edgar, Helmut Tarand 1967. Uusi jooni tegelikus eesnimede ortograafias. - Keel ja Kirjandus 3, 176-177.

Rajandi, Edgar, Helmut Tarand 1969. Anu ,seitsmest" tähendusest. - Keel ja Kirjandus 8, 498-499.

Roos, Eduard 1962. Eesti eesnimede ajaloost XIX ja XX sajandi vahetusel. Keel ja Kirjandus 7, 412-421. 
Rootsmäe, Lemming 1969. Võnnu kihelkonna isikunimed XVIII sajandil. - Keel ja Kirjandus 10, 623-624.

Saard, Riho 2000. Eesti rahvusest luterliku pastorkonna väljakujunemine ja vaba rahvakiriku projekti loomine, 1870-1917. (= Suomen kirkkohistoriallisen seuran toimituksia 184). Helsinki.

Saari, Henn 1990. Ein statistisches Modell der Vornamenwahl. XVIIth International Congress of Onamastic Sciences. Helsinki, August 13-18, 1990. Estnische Akademie der Wissenschaften, Abteilung für Humanitär- und Gesellschaftwissenschaften. (= Preprint KKI-67.) Tallinn.

Schmidt, Arved von 1939 = Die Pastoren Oesels seit der Reformation. (= Abhandlungen des Instituts für wissenschaftliche Heimatforschung an der Livländischen Gemeinnützigen u. Ökonomischen Sozietät 5.) Tartu: J. G. Krüger.

Teder 1939 = Perekonnaseisuametniku käsiraamat. Koost. Teofil Teder. Tallinn: Siseministeeriumi Administratiiv-ala Kirjastus.

Vilbaste, Gustav 1961. Eduard Ahrensi katseid eesti kirikukeele parandamiseks. Emakeele Seltsi aastaraamat VII (1961). Tallinn, 11-16.

\section{Rahvusarhiivi allikad}

Luteri koguduste fondides säilitatavad meetrikaraamatud ning kirikutähed.

EAA.1187.2.1871. Eesti Evangeeliumi Luteri Usu Konsistoorium. Estonisierung der Namen in den Kirchenbüchern. 1891-1892.

EAA.1216.1.11. EELK Kuusalu kogudus. Eestimaa Konsistooriumi ettekirjutused (reskriptid). 1814-1878.

EAA.5281.1.113. EELK Saaremaa praostkond. Akte betreffend die Rechtschreibung der estnischen Tauf- und Familiennahmen. 1903-1904.

Fred Puss

Eesti Isikuloo Keskus

Tiigi 10-51

51003 Tartu

fred@isik.ee 


\title{
Change of spelling style in parish registers
}

\author{
FRED PUSS
}

Until the 1840s old spelling style prevailed in the Estonian language. In 1843 in his grammar Lutheran pastor Eduard Ahrens introduced a new spelling style which was inspired from the Finnish one. Spreading of new style was not rapid and in 1844 only four Lutheran pastors in North Estonia started to use it in their parish registers. In the 1850s only two more joined and in 1867 two first pastors from South Estonia accepted the new style. Lutheran pastors were almost entirely Baltic Germans until that time.

In South Estonia the first pastors to accept the new style were sympathetic to the national awakening of Estonians, which was stronger there and weaker in North Estonia. Also first pastors of Estonian ethnicity appeared in the 1870s in South Estonia and most of them (but not all) started to keep their parish registers in new spelling style.

By 1875 most of published books were already in new spelling style, but some clerical books still appeared in the old style. The New Testament was printed in the new style for the first time in 1888 and the whole bible in 1889.

Of the 110 analysed congregations 76 accepted the new spelling style by 1891 . Mostly it was done in the 1880s (47 congregations), peak years were 1880-1881. Of the pastors who changed the spelling style, 32 were new to the congregation, 17 had worked there from 2-7 years, 13 from $8-15$ years and 11 from $16-36$ years.

The number of changing congregations was quite equal in North and South Estonia (also in absolute numbers). The highest percentage of congregations who accepted the new style was $100 \%$ in Viljandi county, $87 \%$ in Lääne county and $85 \%$ in Harju county. The smallest was $22 \%$ in Võru county, $43 \%$ in Järva county and $47 \%$ in Tartu county. In Võru and Tartu counties possibly the Southern dialect ("Tartu language") was the factor of small style change ratio.

Since 1892 parish registers were ordered to be kept in Russian/Cyrillic and not all pastors added names in Latin alphabet. Thus it is not possible to analyse the spelling change since 1892 in all of Estonia.

Keywords: Estonian language, language history, orthography, paleography, onomastics, language planning 